EMILIA GRZESIAK

ORCID 0000-0001-6678-0298

Uniwersytet im. Adama Mickiewicza

$w$ Poznaniu

\title{
EUDAJMONIZM W DOBIE POKOLENIA Z. ROZWAŻANIA AKSJOLOGICZNE
}

\begin{abstract}
AвSTRACt. Grzesiak Emilia, Eudajmonizm w dobie pokolenia Z. Rozważania aksjologiczne [Eudaimonism in the Era of Generation Z. Axiological Considerations]. Studia Edukacyjne nr 56, 2020, Poznań 2020, pp. 267-296. Adam Mickiewicz University Press. ISSN 1233-6688. DOI: 10.14746/se.2020.56.15

This article deals with the category of happiness and its importance and role for the young people in the 21st century. Happiness in this dimension, however, is not understood as a state of satisfaction (in the individual dimension), but as a goal to which we aspire in our life. The text presents an axiological presentation of the issue, and the considerations cited in the article were referred to one of the ethical positions, which is the idea of eudaimonism.
\end{abstract}

Key words: happiness, eudaimonism, generation Z, values, young people

Res severa est verum gaudium

Seneka, Listy

\section{Wprowadzenie}

Współczesna rzeczywistość to czas wielu przemian, przeobrażeń i ciągłej zmiany. Zdaniem Zygmunta Baumana, żyjemy w płynnej nowoczesności, która charakteryzuje się fragmentarycznością, epizodycznością, niepewnością jednostki, prywatyzacją ambiwalencji oraz przygodnością bytów ${ }^{1}$. Owa efemeryczność, niestałość i niespójność dosięga wielu sfer naszego życia, począwszy od całkiem nieważkich codziennych wyborów, przez jednoznacznie dookreślone w czasie decyzje, po ogólny pogląd na życie, siebie i świat. Wynika to z szeregu różnych, wielokrotnie opisywanych aktualnie zjawisk: mię-

${ }^{1}$ Z. Bauman, Płynne życie, Kraków 2007; tenże, O miejscu teatru w ponowoczesnej sztuce, [w:] Teatr w miejscach nieteatralnych, red. J. Tyszka, Poznań 1998, s. 27. 
dzy innymi postępującego procesu globalizacji ${ }^{2}$, konsumpcjonizmu ${ }^{3}$, inwazji zachodniej kultury ${ }^{4}$, komercjalizacji wszystkich aspektów życia ${ }^{5}$, postępu technologicznego ${ }^{6}$ oraz naukowego; wysokiego tempa życia (o czym świadczy m.in. - nawiązująca do kultury instant - stworzona przez Zbyszko Melosika triada: fast food, fast sex, fast car ${ }^{7}$ ), rosnącego egocentryzmu ${ }^{8}$ (przywołując w tym kontekście społeczeństwo narcyzmu Christophera Lascha ${ }^{9}$ ), sfragmentaryzowania tożsamości ${ }^{10} \mathrm{i}$ w konsekwencji zwiększenia społecznych napięć, niepokojów ${ }^{11}$ i niepewności ${ }^{12}$ (przywołując funkcjonowanie $\mathrm{w}$ "społeczeństwie ryzyka" za U. Beckiem ${ }^{13}$ ), jak również z przeobrażeń na rynku pracy ${ }^{14}$, inflacji dyplomów ${ }^{15}$ oraz intertekstualizmu we współczesnej rzeczywistości ${ }^{16}$. Zygmunt Bauman pisze w tym kontekście następująco:

wszystko lub niemal wszystko w naszym świecie zmienia się: mody, którym ulegamy i przedmioty, którym poświęcamy uwagę, rzeczy, o których marzymy i których się lękamy, rzeczy, których pożądamy i które budzą naszą niechęć, które dają nam nadzieję i które napawają nas niepokojem. Zmieniają się także warunki, w jakich żyjemy, pracujemy i próbujemy planować naszą przyszłość. Okazje do pomnożenia szczęścia

${ }^{2}$ Z. Bauman, Globalizacja, Warszawa 2000, s. 4-15; Z. Melosik, Kontrowersje wokót edukacji globalnej [w:] Teoria i praktyka edukacji wielokulturowej, Kraków 2007, s. 178; A. Bogaj, Konsekwencje procesu globalizacji dla edukacji, [w:] Edukacyjne problemy czasu globalizacji, red. A. Karpińska, Białystok 2003, s. 37; R. Borkowski, Globalizacja, cywilizacja, ponowoczesność, [w:] Globalopolis. Kosmiczna wioska - szanse i zagrożenia, Warszawa 2003, s. 18.

${ }^{3}$ J. Baudrillard, Selected Writings, red. M. Poster, Cambridge 1988, s. 48; za: Z. Melosik, Edukacja, młodzież i kultura wspótczesna: kilka uwag o teorii i praktyce pedagogicznej, Chowanna, 2003, 1, s. 21; tenże, Ponowoczesny świat konsumpcji, [w:] Ciało i zdrowie w społeczeństwie konsumpcji, Torun - Poznań 1999, s. 71; Z. Bauman, Globalizacja, s. 95; tenże, Płynna nowoczesność, Kraków 2006, s. 119; tenże, Konsumowanie życia, Kraków 2009, s. 36.

${ }^{4}$ P. Iyer, The Global Village Finally Arives, "Times", Social Issue, Fall, 1993, s. 86, za: Z. Melosik, Edukacja, młodzież i kultura wspótczesna, s. 21.

${ }^{5}$ Ł. Iwasiński, Społeczeństwo konsumpcyjne w ujęciu Zygmunta Baumana, Kultura i Społeczeństwo, 2015, 4, s. 3.

${ }^{6}$ M. Mrozowski, Media masowe. Wtadza, rozrywka i biznes, Warszawa 2001, s. 45 i 115-116.

7 Z. Melosik, Edukacja, młodzież i kultura wspótczesna, s. 21.

${ }^{8}$ W. Wątroba, Społeczeństwo konsumpcyjne w dobie globalizacji, Wrocław 2006, s. 33.

${ }^{9}$ Ch. Lasch, Kultura narcyzmu, Warszawa 2015, s. 12-34.

10 Z. Bauman, 44 listy ze świata ptynnej nowoczesności, Kraków 2011, s. 28, za: Z. Melosik, Kultura popularna i tożsamość młodzieży. W niewoli władzy i wolności, Kraków 2013, s. 59-63.

${ }_{11}$ Z. Melosik, Edukacja, młodzież i kultura wspótczesna, s. 21.

12 A. Giddens, Nowoczesność i tożsamość. "Ja" i społeczeństwo w epoce późnej nowoczesności, Warszawa 2001, s. 274.

${ }^{13}$ U. Beck, Społeczeństwo ryzyka. W drodze do innej nowoczesności, Warszawa 2004; A. Giddens, Nowoczesność i tożsamość, s. 150-197.

14 A. Gromkowska-Melosik, Stratyfikacja, ruchliwość spoteczna, edukacja - kilka uwag teoretycznych, [w:] Edukacja i stratyfikacja społeczna, red. T. Gmerek, Poznań 2003, s. 23-36. s. 116 .

15 Z. Melosik, Uniwersytet i społeczeństwo. Dyskursy wolności, wiedzy i władzy, Kraków 2009,

${ }^{16}$ T. Gmerek, Dyskursy męskości w reklamie wspótczesnej, [w:] Kultura popularna i (re)konstrukcje tożsamości, red. A. Gromkowska-Melosik, Poznań - Leszno 2007, s. 217-218. 
i groźne zapowiedzi nieszczęścia zjawiają się i znikają, nadciągają i umykają, na ogół zbyt szybko i zwinnie, abyśmy mogli w jakiś rozsądny i skuteczny sposób pokierować ich biegiem, kontrolować czy przewidywać ich ruchy. Mówiąc krótko, nasz świat, świat płynnej nowoczesności, nieustannie nas zaskakuje ${ }^{17}$.

Opis ten idealnie koresponduje z myślą Heraklita pantha rei (wszystko płynie), gdyż można odnieść wrażenie, że we współczesnej rzeczywistości istotnie wszystko zmienia się, płynie, pędzi oraz ulega ciągłym przeobrażeniom. Zmieniają się aspiracje, plany, dążenia. Zmieniają się cele, wartości, przekonania i sens istnienia. Najlepiej widać to na przykładzie kolejnych, wchodzących w dorosłość pokoleń, które wydawać by się mogło już coraz mniej przypominają te sprzed trzydziestu, czterdziestu, czy pięćdziesięciu lat. Stąd pojawiło się pytanie, co w tak szybko zmieniającym się, niepewnym ${ }^{18}$, stechnologizowanym świecie staje się największą wartością. Co w rzeczywistości, w której - paradoksalnie - mamy do czynienia z upadkiem wielkich metanarracj ${ }^{19} \mathrm{i}$ tradycyjnych wartości, i w której prym wiedzie wolność wyboru i nieredukowalność indywidualnych różnic (przekonań, celów i sensów) ${ }^{20}$, wpływa na kształt naszych preferencji, staje się przedmiotem marzeń, krystalizuje aspiracje i motywuje do dalszych działań? Do czego dąży i czym charakteryzuje się kolejne pokolenie wchodzących w dorosłość osób? Czym dla nich jest szczęście i w czym owe szczęście może się urzeczywistniać? Co ich prawdziwie zajmuje, w czym upatrują sens istnienia i jakimi wartościami kierują się w życiu? Pozostaje również pytanie, czy na wszystkie powyższe można odnaleźć - w płynnym, maksymalnie sfragmentaryzowanym świecie - jedną spójną odpowiedź?

Przedmiotem rozważań w niniejszym artykule będzie zagadnienie szczęścia, jednak nie rozumianego jako subiektywnie odczuwany stan zadowolenia (w wymiarze jednostkowym), ale jako cel (wartość sama w sobie), do którego w życiu dążymy. Dokonam w nim próby aksjologicznego zaprezentowania tematu, a przywołane $\mathrm{w}$ artykule rozważania zostaną odniesione do jednego ze stanowisk etycznych, jakim jest idea eudajmonizmu.

\section{Eudajmonizm - znaczenie pojęcia}

Na wstępie warto zastanowić się, czym w istocie jest eudajmonizm. Po-

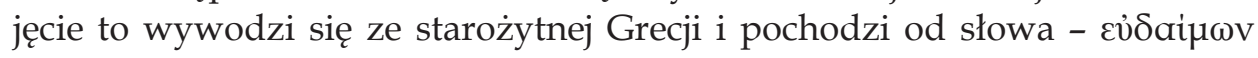

17 Z. Bauman, 44 listy ze świata płynnej nowoczesności.

${ }_{18}$ B. Majerek, Młody prekariat, czyli codzienna niepewność, [w:] Codzienność jako wyzwanie edukacyjne, Wrocław 2017, s. 93-99.

19 Z. Melosik, Edukacja, młodzież i kultura wspótczesna, s. 19-21.

${ }^{20}$ Z. Bauman, Nowoczesność i ponowoczesność, [w:] Encyklopedia socjologiczna, t. II, Warszawa 1999, s. 353. 
- eudaimōn, co oznacza "szczęśliwy”, "mający dobrego ducha” (eu - dobry, daimon - duch $)^{21}$. W Encyklopedii PWN znajdujemy zapis, iż eudajmonizm to „pogląd etyczny, według którego szczęście jest najwyższym dobrem i ostatecznym celem człowieka"22. Pojęcie to oznaczało „etyczną koncepcję życia w zgodzie z samym sobą, ze swoim prawdziwym ,ja”" (gr. daimon)23. Jak już zostało wspomniane, to nie tylko chwilowy stan pozytywnych emocji czy szeroko rozumianego zadowolenia i spełnienia, ale swoistego rodzaju zadanie do zrealizowania, cel, do którego dążymy w życiu ${ }^{24}$. Był on ściśle związany z poczuciem satysfakcji z przebytej ścieżki życiowej, co stanowiło fundamentalny azymut dla każdej istoty ludzkiej ${ }^{25}$. Z uwagi na to, że eudajmonia nie charakteryzowała się nigdy jednoznacznie dookreśloną definicją i jasnymi ramami znaczeniowymi, rozmaite osoby (w tym greccy uczeni), które preferowały ten filozoficzny pogląd, nie były zgodne pod względem rozumienia tego, czym jest w istocie szczęście. Każdy mógł rozumieć i definiować je inaczej. Dla jednych mogła to być cnota, Bóg, praca, luksus, dla innych - przyjemność, nirwana czy ekstaza. I na przykład, dla Arystotelesa i Epikura był to skutek intencjonalnego i rozumnego postępowania człowieka oraz zaspokajania swoich wszystkich - zarówno duchowych, jak i cielesnych - potrzeb (szczęście było związane z doznaniami intelektualnymi i należało sobie je niejako „wypracować” poprzez właściwe zachowanie i zrównoważone postępowanie). Sokrates i Platon rozumieli szczęście jako „stan doskonałości swojego życia", kiedy to jednostka w okresie starości patrzy na swoje życie z satysfakcją i nie żałuje żadnej podjętej decyzji. Dla św. Tomasza z Akwinu i św. Augustyna było to wpatrywanie się w Boga (i perspektywa nieba w przyszłości), z kolei dla Demokryta z Abdery stanowiło poczucie satysfakcji i zadowolenia z odczuwanego stanu ładu i harmonii (a więc celem było permanentne poszukiwanie w życiu spokoju i harmonii w ujęciu holistycznym). Dla epikurejczyków szczęściem była przyjemność (i to wokół tej kategorii funkcjonowali i zgodnie z nią podejmowali poszczególne aktywności wierząc, że jeśli tylko odczuwamy więcej pozytywnych aniżeli negatywnych emocji, to już jesteśmy w stanie eudajmonii), a dla zwolenników stoicyzmu - cnota (tak rozumiana eudajmonia była ściśle związana ze stanem wewnętrznym, który można osiągnąć na skutek rzetelnego i sumiennego wykonywania swoich obowiązków, kierowania się rozumem i nie podążania za przyjemnościami i uciechami ży-

${ }^{21}$ Encyklopedia popularna PWN, Warszawa 1997-2019.

${ }^{22}$ Tamże.

23 A. Bujacz, E. Hornowska, Hedonizm i Eudajmonizm w badaniach psychologii pozytywnej, Psychologia Jakości Życia, 2012, 11, 1, s. 105.

${ }^{24}$ A.S. Waterman, Two conceptions of happiness: Contrasts of personal expressiveness (eudaimonia) and hedonic enjoyment, Journal of Personality and Social Psychology, 1993, 64, s. 678-691; V. Frankl, Paradoksy szczęścia, Życie i Myśl, 1977, 1, s. 33-45.

${ }^{25}$ W. Tatarkiewicz, O szczęściu, Warszawa 1990. 
cia ${ }^{26}$ oraz postawą akceptacji i zgody na wszystko, co przynosi życie - zarówno biorąc pod uwagę te pozytywne, jaki i te negatywne wydarzenia. Uważało się też, iż jest ona dostępna dla ludzi oświeconych) ${ }^{27}$.

W ramach tego podejścia dokonuje się niekiedy podziału na eudajmonizm transcendentny i immanentny. Pierwszy związany jest z łączeniem szczęścia w sposób nierozerwalny z absolutem (Bogiem), ma wymiar pozaziemski (tj. łączy oba światy - doczesny i wieczny) i przykładem takiego jego rozumienia może być chrześcijaństwo lub platonizm. Drugi z kolei - eudajmonizm immanentny - odpowiada życiu doczesnemu i związanymi z nim dobrami. Dzieli się on na eudajmonizm immanentny subiektywny - związany z przeżyciami indywidualnymi jednostki lub też większej zbiorowości (może przybierać postać hedonizmu - w ujęciu indywidualnym lub utylitaryzmu - w ujęciu zbiorowym) oraz obiektywny - związany z osiąganiem, zdobywaniem, gromadzeniem poszczególnych, powszechnie uznawanych, obiektywnych dóbr (czy to materialnych, czy to niematerialnych - duchowych) ${ }^{28}$.

Warto $\mathrm{w}$ tym miejscu wspomnieć, że kategoria szczęścia w psychologii pozytywnej rozpatrywana jest w ramach dwóch nurtów: hedonizmu i eudajmonizmu. Obydwa pojęcia nawiązują do idei dobrego życia i w obu pojęciach kategoria szczęścia stanowi wartość samą w sobie ${ }^{29}$. W perspektywie eudajmonistycznej skupiamy się jednak w sposób nadrzędny na dążeniu do doskonałości i jest ona nakierowana na przyszłość, a nie na nasze subiektywne doznania o zabarwieniu pozytywnym (które oczywiście mogą wystąpić, ale nie są najważniejsze - stanowią raczej dodatkową konsekwencję posiadania dobrego życia). W ujęciu hedonistycznym z kolei nasze subiektywne doświadczenia wydają się być najistotniejsze - poczucie szczęścia wiąże się z minimalizacją tych negatywnych wrażeń, doznań i doświadczeń, a maksymalizacją i mnożeniem tych pozytywnych momentów, stanów, uczuć i emo$\mathrm{cji}^{30}$. Tak rozumiane szczęście jest mocno osadzone w teraźniejszości, odnosi się do skupiania na tym co tu i teraz oraz gloryfikacji kategorii przyjemności.

W odniesieniu do przywołanej powyżej kategorii szczęścia, w tym miejscu można dokonać analizy jego aktualnych egzemplifikacji w ramach współczesnych przemian rzeczywistości, jak również dokonujących się zmian pokoleniowych (szczególnie mając na uwadze wchodzące w dorosłość pokolenie dzisiejszych nastolatków).

${ }^{26}$ M. Wnuk, Hedonizm, eudajmonizm oraz przeptyw/zaangażowanie jako trzy nurty badań nad szczęściem, Hygeia Public Health, 2013, 48(3), s. 285.

27 Encyklopedia popularna PWN.

${ }^{28}$ Tamże.

${ }^{29}$ W. Tatarkiewicz, O szczęściu.

${ }^{30}$ R.M. Ryan, E.L. Deci, On happiness and human potentials: A review of research on hedonic and eudajmonic research, Annual Reviews Psychol, 2001, 52, s. 141-166. 


\section{Pokolenie Z - charakterystyka}

W pierwszej kolejności warto dokonać charakterystyki współczesnego pokolenia, które niejednokrotnie określane jest mianem pokolenia Z (ang. Generation Z). Jego przedstawiciele urodzili się po roku 2000, a więc w rozkwicie ery Internetu. Jednakże, należy zwrócić uwagę, iż niekiedy ramy czasowe mające określić początek tej generacji bywają różne. Można spotkać się z informacjami, iż do pokolenia $Z$ należą osoby urodzone na przykład po roku 199031; nie wcześniej niż w latach 1990-1995 (lub 1997 roku $^{32}$ ) lub w 1995 roku $^{33}$. Niemniej jednak, jest to kolejna, po Baby Boomers (1946-1964 - powojennym pokoleniu wyżu demograficznego), pokoleniu X (1965-1979), pokoleniu Y (1980-1994 (5 lub 9) - określanych mianem Millenialsów ${ }^{34}$ ), generacja osób, która stanowi obecnie najmłodsze pokolenie wchodzące na rynek pracy (co ciekawe, już teraz wymienia się także pokolenie alfa, które odnosi się do osób urodzonych po 2010 roku) ${ }^{35}$. Pokolenie $\mathrm{Z}$ ma wiele alternatywnych określeń. Nazywane jest generacją Z, pokoleniem C (od angielskich słów connect, communicate, change ${ }^{36}$, generacją Post-Millennials, pokoleniem internetowym ${ }^{37}$, ,generacją multitasking" 38 , "generacją @”, pokoleniem $\mathrm{XD}^{39}$, pokoleniem iGen, “iGeneration", “Digital Natives", "Me Generation", "Generation N"40, "digital X"41

${ }^{31}$ M. Pawłowska, Generacja Z. Młodzi, otwarci, wychowani w dobrobycie, żyjacy w świecie wirtualnym, skazani na kryzys, źródło: https://natemat.pl/55617,generacja-z-mlodzi-otwarci-wychowani-w-dobrobycie-zyjacy-w-swiecie-wirtualnym-skazani-na-kryzys, [dostęp: 15.07.2019].

32 K. Skrzydłowska-Kalukin, „Wprost”: Zet idzie do pracy, źródło: wiadomosci.wp.pl, [dostęp: 15.07.2019]; M. Kostyńska, Pokolenie Z, czyli pokolenie nowoczesnych technologii $i$ Internetu, źródło: https://msp.money.pl/wiadomosci/poradniki/artykul/pokolenie-z-czyli-pokolenienowoczesnych,81,0,2419537.html, [dostęp: 15.07.2019].

33 A. Williams, How to Spot a Member of Generation Z, „The New York Times”, 18 września 2015; Understanding Gen Z. Insights on their behavior, financial knowledge and spending patterns, Synchrony, August 2018, s. 2, źródło: https://www.synchrony.com/2018genzwhitepaper.pdf, [dostęp: 20.09.2019].

${ }_{34}$ M. Walków, Pokolenia na rynku pracy w Polsce - kim są baby boomers, X, Y i C?, źródło: https:/ / businessinsider.com.pl/rozwoj-osobisty/kariera/millenials-pokolenie-x-y-z-i-baby-boomers-kim-sa-na-rynku-pracy/6e53lmr, [dostęp: 15.07.2019].

35 B. Sajduk, Pokolenie Y a metody dydaktyki akademickiej, „Kultura i Polityka”, 2014, 16.

${ }^{36}$ M. Walków, Pokolenia na rynku pracy w Polsce.

37 M. Kostyńska, Pokolenie Z, czyli pokolenie nowoczesnych technologii i Internetu.

${ }^{38}$ Grupa Wirtualna Polska, Pokolenie Z - nie warto bronić im dostępu do nowych technologii, źródło: „dzieci.pl”, [dostęp: 15.07.2019].

39 K. Rakosza, Zapomnijcie o "generacji $Y^{\prime}$. Do głosu dochodzi "pokolenie XD" - $i$ łatwo je rozpoznać, źródło: https://natemat.pl/235903,do-jakiego-pokolenia-naleze-generacja-z-to-najliczniejsza-grupa-w-polsce, [dostęp: 15.09.2019].

${ }^{40}$ M.S.M. Salleh, N.N. Mahbob, N.S. Baharudin, Overview of "Generation Z" Behavioural Characteristic and its Effect Towards Hostel Facility, International Journal of Real Estate Studies, 2017, 11, 2, s. 59.

41 R. Sadowski, Raport Newspoint: Pokolenia w Polsce i potrzeba monitorowania ich rosnacej aktywności, źródło: https://blog.newspoint.pl/index.php/2018/03/21/raport-newspoint-pokolenia-w-polsce-i-potrzeba-monitorowania-ich-rosnacej-aktywnosci/, [dostęp: 15.07.2019]. 
lub też określa je pojęciem Digitarianie (od ang. digitarians) ${ }^{42}$, a także Centennials ${ }^{43}$, Pluralist Generation lub Plurals ${ }^{44}$.

Do cech charakteryzujących pokolenie „Z" z pewnością należy fakt, że od najmłodszych lat funkcjonują w stechnologizowanej rzeczywistości, potrafią szybko analizować informacje (które najczęściej czerpią z Internetu) i sprawnie poruszać się poświecie wirtualnym ${ }^{45}$. Nie pamiętają czasów sprzed wejścia do Unii Europejskiej. Żyją w kulturze upozorowania, gdzie niejednokrotnie „rzeczywistość medialna i realna miesza się do granic nierozróżnialności” ${ }^{46}$. Mają świadomość życia w świecie ciągłej zmiany, braku stabilizacji oraz postępującej automatyzacji (są np. świadomi, że w ciągu swojego życia kilkakrotnie - a nawet kilkunastokrotnie - będą musieli zmienić miejsce pracy) - są realistami ${ }^{47}$. Wydają się pragmatyczni ${ }^{48}$, ambitni oraz otwarci na nową wiedzę i nowe doświadczenia ${ }^{49}$. Określa sięje jako osoby bezpośrednie i twórcze ${ }^{50}$, potrafiące niejednokrotnie zajmować się kilkoma sprawami równocześnie (charakteryzuje je wrodzony multitasking ${ }^{51}$ ), jednak miewające problemy z koncentracją. Uważa się, iż są w dużej mierze niepewni (w odniesieniu do swojej przyszłości i tego, co jeszcze przed nimi), bywają powierzchowni w ocenie i analizie różnych sytuacji, roszczeniowi, nierzadko egoistyczni ${ }^{52}$ oraz nie potrafią „usiedzieć długo w jednym miejscu” ${ }^{53}$. Z łatwością ulegają trendom ${ }^{54}$

${ }^{42}$ A. Zborowska, Płaca i fun, źródło: https://www.newsweek.pl/wiedza/pokolenie-z-wchodzi-na-rynek-pracy/tln79x3, [dostęp: 20.09.2019].

43 A. Williams, How to Spot a Member.

44 The Plurals Are Coming: What Universities Need To Know, źródło: https://www.modolabs. com/blog-post/the-plurals-are-coming-what-universities-need-to-know/, [dostęp: 15.07.2019].

${ }_{45}$ A generation without borders. Embracing Generation Z, OC\&C, 2019, s. 5, źródło: https:// www.occstrategy.com/media/1806/a-generation-without-borders.pdf, [dostęp: 20.09.2019].

${ }^{46}$ Z. Melosik, Kultura upozorowania, [w:] Pedagogika. Podręcznik akademicki, tom 2, red. Z. Kwieciński, B. Śliwerski, Warszawa 2007, s. 76-78; A. Dolot, The characteristic of Generation Z, e-mentor, 2018, s. 44-50, http://dx.doi. org/10.15219/em74.1351, s. 45.

${ }^{47}$ M. Rojewska, Kim sa milenialsi, pokolenie X, Y, Z i baby boomers [Pokolenia w pracy], źródło: https://interviewme.pl/blog/pokolenie-z. [dostęp: 15.07.2019].

${ }^{48}$ J. Desjardins, Meet Generation Z: The Newest Member to the Workforce, źródło: https:/ / www.visualcapitalist.com/meet-generation-z-the-newest-member-to-the-workforce/, [dostęp: 20.09.2019].

49 The Everything Guide to Generation Z, Vision Critical With research by Maru/VCREC, s. 3, źródło: https://cdn2.hubspot.net/hubfs/4976390/E-books/English\%20e-books/The\%20everything\%20guide\%20to\%20gen\%20z/the-everything-guide-to-gen-z.pdf, [dostęp: 15.09.2019].

${ }_{50}$ R. Half, Get ready for Generation Z, 2015, źródło: http://www.ncfef.com/resources/Presentations/2017_Events/GenZ.pdf, [dostęp: 20.09.2019].

${ }^{51}$ S. Robertson, Generation $z$ characteristics \& traits that explain the way they learn, źródło: https://info.jkcp.com/blog/generation-z-characteristics, [dostęp: 15.09.2019].

52 Jak zrozumieć dziś pokolenie jutra. Raport - wersja demo, red. M. Jungiewicz, Gańsk - Warszawa 2019, s. 3.

${ }^{53}$ M. Walków, Pokolenia na rynku pracy w Polsce.

${ }^{54}$ Understanding Gen Z Insights on their behavior, financial knowledge and spending patterns, s. 4-9. 
i uważa się ich za stawiających wysokie wymagania indywidualistów ${ }^{55}$. Philip Kotler zwraca uwagę, iż

odróżnia ich wysoka mobilność. Wszystko muszą mieć natychmiast - nie mogą marnować czasu. Gdy widzą coś, co im się podoba w telewizji, od razu szukają tego w Internecie za pomocą swoich przenośnych urządzeń. Gdy decydują się na zakup czegoś w sklepie, najpierw porównują ceny i jakość online. (...) Są również bardzo towarzyscy i udzielają się w mediach społecznościowych. (...) Mówiąc krótko, są mocno powiązani z innymi ludźmi i mają stały dostęp do Internetu ${ }^{56}$.

\section{Wartości młodego pokolenia}

W tym miejscu pojawia się pytanie, jakimi wartościami kieruje się w życiu pokolenie Z. Co może być zaskakujące, zgodnie z najnowszym raportem, zatytułowanym „Jak zrozumieć dziś pokolenie jutra"57, okazuje się, że „niewiele różnią się od innych pokoleń - (...) najważniejsze jest dla nich to, co generalnie ważne jest dla każdego człowieka: miłość, bezpieczeństwo i rozwój osobisty" ${ }^{58}$. W raporcie "Understanding Gen Z" czytamy, że generacja ta charakteryzuje się podobnymi do innych obywateli wartościami, takimi jak: uczciwość, niezawodność i zaangażowanie, jednak $\mathrm{w}$ odróżnieniu do poprzednich pokoleń patrzy na świat nie przez pryzmat wartości hierarchicznych, a indywidualistycznych (co odnosi się do przesunięcia socjalizacyjnego i utraty autorytetu starszych pokoleń $)^{59}$. Oprócz tego są bardziej skoncentrowani na karierze, własnych zainteresowaniach i wyglądzie zewnętrznym, natomiast mniejsze znaczenie (w porównaniu z poprzednimi pokoleniami) mają dla nich wartości patriotyczne, orientacja seksualna i religia ${ }^{60}$. Informacje zawarte w raporcie "Pokolenie Z $w$ finansach i na rynku pracy" świadczą o tym, iż "Zetki w porównaniu z osobami z pokolenia X i Y będą żyły dłużej, w większych i lepiej wyposażonych mieszkaniach. Będą mniej religijne lub ich religijność będzie miała inny wymiar. Później będą zakładały rodziny i częściej żyły w niesformalizowanych związkach. „W świecie pełnym dóbr konsumpcyjnych i zachodzących zmian społecznych wolność i swoboda wyboru będą dla nich kluczowymi wartościami" ${ }^{61}$. Z ko-

${ }_{55}$ J. Szymczyk, Pokolenie Z na rynku pracy - charakterystyka, źródło: https:/ / poradnikprzedsiebiorcy.pl/-pokolenia-w-pracy-cz-4-pokolenie-z, [dostęp: 15.07.2019].

${ }^{56}$ P. Kotler, Marketing 4.0, New Jersey 2017, za: R. Sadowski, Raport Newspoint.

${ }^{57}$ Jak zrozumieć dziś pokolenie jutra. Raport - wersja demo, red. M. Jungiewicz.

58 Tamże.

59 Understanding Gen Z. Report, Morning Consult, s. 7-8, źródło: https://morningconsult. com/wp-content/uploads/2019/06/Morning-Consult-Understanding-Gen-Z.pdf,[dostęp: 15.09.2019].

${ }^{60}$ Tamże.

${ }^{61}$ Pokolenie $\mathrm{Z} w$ finansach i na rynku pracy. Jak pokolenia $Z, X$ i Y różnią się w świetle danych i badań, Raport. SPOTDATA, s. 5, źródło: https://www.pb.pl/pokoleniez/download/pokolenie_z_raport_spotdata.pdf, [dostęp: 15.07.2019]. 
lei, według informacji zawartych w raporcie "Generation Z Looks a Lot Like Millennials on Key Social and Political Issues", opublikowanym przez Pew Research Center w styczniu 2019 roku, generacja Z charakteryzuje się bardzo liberalnymi poglądami (w porównaniu z poprzednimi generacjami) oraz otwartą postawą na pojawiające się tendencje społeczne ${ }^{62}$. Inne źródła z kolei podają, iż

jest to pokolenie twórców kultury (CC Creators), które na nowo definiują rozrywkę, konsumpcję, miejsce pracy i marketing. CC są silnymi, skomunikowanymi, empatycznymi „self-starters'ami”63, którzy chcą się wyróżniać i zmieniać świat. Stworzyli nową „walutę kulturową", która ceni wyjątkowość, autentyczność, kreatywność, (...) i uznanie ${ }^{64}$.

Wyniki badań przeprowadzonych w 2017 roku przez McKinsey we współpracy z agencją badawczą Box1824 wskazują, że generacja Z ceni indywidualną ekspresję i aktywność własną, ale unika etykiet, stygmatyzowania i stereotypowego myślenia. Osoby należące do tego pokolenia mobilizują się wzajemnie i prawdziwie wierzą w skuteczność dialogu w rozwiązywaniu konfliktów oraz procesie udoskonalania świata ${ }^{65}$. O ile można odnaleźć szereg różnych koncepcji dotyczących wartości i pryzmatu postrzegania rzeczywistości przez generację Z - o czym świadczą między innymi przywołane wyniki badań - o tyle Aleksandra Zborowska w swoim artykule zwraca uwagę, iż dla „pokolenia urodzonego w analogowym świecie, digitarianie są wciąż niewiadomą, która budzi obawy"66, po czym można wnioskować, że choć możemy przewidywać różne scenariusze, to jednak prawdziwą i wiarygodną odpowiedź może przynieść jedynie przyszłość.

\section{Pryzmaty postrzegania szczęścia (w opinii studentów)}

W obliczu przywołanych wyżej argumentów postanowiłam w sposób indywidualny poszukać, niejako u źródła, odpowiedzi na pytanie o charakterze problemowym: „Czym dla młodego - wchodzącego w dorosłość i żyjącego

${ }^{62}$ Generation Z Looks a Lot Like Millennials on Key Social and Political Issues, Pew Research Center, January 2019, s. 2; Ipsos Thinks. Beyond Binary. The lives and choices of Generation Z, s. 19, źródło: https://www.ipsos.com/sites/default/files/2018-08/ipsos_-_beyond_binary_-_the_lives_and_choices_of_gen_z.pdf, [dostęp: 15.09.2019].

${ }^{63}$ Jest to określenie odnoszące się do osób ambitnych i zmotywowanych do otworzenia własnego biznesu, rozpoczęcia nowej kariery lub kontynuowania edukacji - na własną rękę $\mathrm{i}$ bez pomocy innych.

${ }^{64}$ M. Kleinschmit, Generation Z Characteristics: 5 Infographics on the Gen Z Lifestyle, źródło: https://www.visioncritical.com/blog/generation-z-infographics, [dostęp: 15.09.2019].

${ }^{65}$ T. Francis, F. Hoefel, 'True Gen': Generation Z and its implications for companies, źródło: https://www.mckinsey.com/industries/consumer-packaged-goods/our-insights/true-gengeneration-z-and-its-implications-for-companies, [dostęp: 15.09.2019].

${ }^{66}$ A. Zborowska, Ptaca i fun. 
w dobie XXI wieku - pokolenia jest szczęście?" Miało ono na celu dostarczyć wstępnej wiedzy odnoszącej się do współczesnego rozumienia szczęścia przez wchodzące $w$ dorosłość pokolenie oraz informacji odnośnie tego, jak współcześni młodzi ludzie rozumieją to pojęcie, z czym się ono wiąże oraz jakie wartości mu przypisują. Przedmiotem dokonanego rozpoznania było zatem pojęcie szczęścia i jego miejsce (poprzez indywidualnie nadawane znaczenia) w życiu młodych ludzi. Zapytałam o to studentów II roku studiów licencjackich kierunku pedagogika (Uniwersytet im. Adama Mickiewicza w Poznaniu; Wydział Studiów Edukacyjnych), będących zarówno przedstawicielami współczesnego młodego pokolenia, jak również aktywnymi obserwatorami i uczestnikami współczesnej rzeczywistości społeczno-kulturowej. Byli to przedstawiciele grup konwersatoryjnych, z którymi podejmowałam zagadnienia dotyczące problemów współczesnej kultury i edukacji. Postawione pytanie stanowiło uzupełnienie i zarazem podsumowanie zajęć dotyczących przemian współczesnej rzeczywistości i konsumpcyjnego stylu życia. W tym wstępnym rozpoznaniu, które miało miejsce na przełomie marca i kwietnia 2019 roku, korzystając z podejścia, jakim jest analiza treści ${ }^{67}$ (content analysis ${ }^{68}$, a dokładniej - jakościowa analiza wytworzonych celowo treści $z$ wyłanianiem kategorii), udział wzięło 147 osób (w tym 141 kobiet i 6 mężczyzn). Każda osoba miała za zadanie wypowiedzieć się na ten temat w formie pisemnej. Uzyskane informacje o charakterze anonimowym miały pozwolić na pozyskanie jak najszczerszych odpowiedzi (niekiedy studenci wpisywali nazwę swojej specjalności, jednak nie był to warunek konieczny) ${ }^{69}$.

Zastosowane podejście pozwoliło na zgromadzenie dużej liczby danych (w tym przypadku wywołanych przez badacza ${ }^{70}$ ), dotyczących współczesnego rozumienia szczęścia przez studentów, biorąc pod uwagę przemiany współczesnej rzeczywistości, jak również osobiste doświadczenia i wyznawany przez studentów system wartości. $W$ ramach realizowanego tematu wyodrębniono jeden problem główny zamykający się $\mathrm{w}$ pytaniu: Jakie znaczenia pojęciu szczęście nadaja studenci pedagogiki? oraz następujące problemy szczegółowe: Z jakimi obszarami życia i wartościami wią̇a kategorię szczęścia?; Jakie sytuacje i zdarzenia traktuja jako powiązane z odczuwaniem szczęścia?; Co dla studentów pedagogiki jest istotą szczęścia w dobie XXI wieku?

W toku analizy uzyskanych odpowiedzi zwróciłam uwagę na następujące kategorie: refleksyjność (czy nadawane znaczenia są pogłębione), spójność, hie-

${ }^{67}$ D. Langdridge, Introduction to research methods and data analysis in psychology, Buckingham 2004, s. 152-153.

${ }^{68}$ K. Krippendorff, Content analysis. An introduction to its methodology, Thousand Oaks 2004, s. 1-8.

${ }^{69} \mathrm{~W}$ artykule zaprezentowano oryginalne wypowiedzi studentów.

70 T. Rapley, Analiza konwersacji, dyskursu i dokumentów, Warszawa 2010. 
rarchizacja (czy są uporządkowane systemowo), personalizacja (czy są odnoszone do siebie czy lokowane w znaczeniach ogólnych) oraz ulokowanie (czy wiązane są ze zdolnością/ umiejętnością jednostki do odczuwania szczęścia czy przeciwnie - z zewnętrznymi warunkami). Na potrzeby niniejszego artykułu skupię się jednak wyłącznie na sposobach postrzegania szczęścia, biorąc pod uwage jego definicję oraz istotę w rozumieniu studentów, przyjmując za M. Lisowską-Magdziarz statystyczny model analizy - „prowadzący do możliwie systematycznego opisu fragmentu rzeczywistości nakierowanego na zliczanie ilości, częstości, rozmiarów, nasilenia określonych elementów"71.

W tym miejscu należy zwrócić uwagę na to, iż biorąc pod uwage ograniczenia zastosowanego podejścia, subiektywność danych (wynikający niejednokrotnie z biograficznego kontekstu wypowiedzi), jak również brak zastosowania triangulacji w celu głębszej analizy niniejszego zagadnienia, mam świadomość, iż uzyskane wyniki stanowią jedynie wstępną charakterystykę określonego wycinka rzeczywistości oraz mogą być odniesione wyłącznie do konkretnej grupy społecznej (w tym przypadku studentów pedagogiki na Uniwersytecie im. Adama Mickiewicza w Poznaniu), dlatego też nie należy ich uogólniać. Mają one jedynie charakter wstępnej analizy ukazującej rozliczność sposobów rozumienia, definiowania i postrzegania (nierzadko przez pryzmat własnych doświadczeń) kategorii szczęścia.

Po uporządkowaniu zebranego materiału, w celu klasyfikacji uzyskanych odpowiedzi, dokonałam identyfikacji wątków (obszarów tematycznego lokowania szczęścia) ${ }^{72}$, to jest kodowania (rozumianego jako „klasyfikowanie lub kategoryzowanie pojedynczych fragmentów danych połączone z jakimś systemem ich odszukiwania"73) i pozwoliłam je sobie pogrupować tworząc 10 kategorii (które stanowiły podstawę do rekonstrukcji znaczeniowej zawartości wątków). Przedstawiają się one w sposób następujący:

- wielowymiarowość i wielokontekstowość podejść do kategorii szczęścia (odwieczny dylemat moralno-egzystencjalny; różne sposoby i drogi do osiągnięcia szczęścia);

- status materialny (zasobność portfela, dobra materialne);

- prestiż społeczny (atrakcyjność fizyczna, pozycja społeczna, sukces, przyjemność, maksymalizacja wrażeń i uczestnictwo w cenionych współcześnie praktykach kulturowych);

- praca (dobrze płatny, prestiżowy zawód, kariera, osiągniecie sukcesu);

- samorozwój (inwestowanie w siebie, podnoszenie kwalifikacji; rozwijanie pasji i zainteresowań, satysfakcja z życia);

${ }^{71}$ M. Lisowska-Magdziarz, Analiza zawartości mediów. Przewodnik dla studentów, Kraków 2004, s. 53.

${ }_{72}$ K.N. Denzin, S.Y. Lincoln, Metody badań jakościowych, Warszawa 2009, s. 326.

${ }^{73}$ E. Babbie, Podstawy badań społecznych, Warszawa 2008, s. 428. 
- rodzina i przyjaciele (miłość, wsparcie, poczucie przynależności; wspólnie spędzony czas);

- kontakty i aktywność w życiu społecznym (szczere, autentyczne relacje, kontakty międzyludzkie, obecność drugiego człowieka);

- troska o innych (miłość, przyjaźń, możliwość zrobienia czegoś dla drugiej osoby, sprawianie przyjemności, dzielenie radości, pomoc);

- stabilizacja (stabilność w życiu, poczucie bezpieczeństwa);

- życie w zgodzie z samym sobą (akceptacja samego siebie, poczucie wolności, odnalezienie własnego "ja”, życie w zgodzie i prawdzie, harmonia, spokój, wiara).

W kodowaniu przyjęto jedną z istniejących orientacji analizy tematycznej, a mianowicie analizę refleksyjną, zapewniającą elastyczność kodowania i tworzenie kodów w trakcie procesu badawczego. Poniżej przedstawiono najważniejsze wnioski w ujęciu syntetycznym.

Okazuje się, iż w opinii studentów kierunku pedagogika kategoria szczęścia jest kwestią indywidualną i wielowymiarową. Zdają sobie oni sprawę, że każdy może postrzegać je inaczej (8 odpowiedzi). Wskazuje to na sfragmentaryzowanie współczesnej rzeczywistości - odwołując się do koncepcji intertekstualizmu i postrukturalizmu - czego egzemplifikacją jest fakt, iż współczesna kultura składa się z różnorodnych tekstów kulturowych, które są pełne „luk, sprzeczności i nieadekwatności"74, a samo „znaczenie tekstu nie istnieje autonomicznie w tekście" 75 . Prowadzi to do tego, że każdy uczestnik kultury, a tym samym odbiorca poszczególnych tekstów kulturowych, może samodzielnie nadawać znaczenia, "konteksty” temu wszystkiemu, co widzi i czego doświadcza w świecie. Jest to także swoistego rodzaju wyjście (przez świat konsumpcyjny, rzeczywistość medialną i wszechobecne reklamy) naprzeciw różnym gustom i potrzebom odbiorców, aby jak najlepiej spełnić indywidualne oczekiwania potencjalnych klientów-konsumentów ${ }^{76}$. Owe „rozproszenie" w sposobach rozumienia i postrzegania kategorii szczęścia można odnieść także do procesu konstruowania własnej tożsamości i (powołując się na pojęcia zaproponowane przez Z. Baumana) obserwowanego współcześnie odejścia od tożsamości ,ze spiżarni” oraz zastąpienia jej tożsamością „,ze skle$\mathrm{pu}^{\prime \prime}$. Związane jest to bezpośrednio z przejściem od tradycyjnych wartości, uporządkowanego życia i solidnie konstruowanej, osadzonej na mocnych fundamentach, tożsamości w stronę niekończącego się procesu „odkrywania własnej tożsamości” i własnego ,ja” w świecie

${ }^{74}$ Z. Melosik, Postmodernistyczne kontrowersje wokót edukacji, Poznań - Torun 1995, s. 233; za: T. Gmerek, Dyskursy męskości, s. 218-219.

75 Z. Melosik, Tożsamość, ciało i władza. Teksty kulturowe jako (kon)teksty pedagogiczne, Poznań - Toruń 1996, s. 41-43; za: T. Gmerek, Dyskursy męskości, s. 218-219.

${ }^{76}$ T. Gmerek, Dyskursy męskości, s. 219. 
gdy to ja, jednostka wybierająca i ponosząca konsekwencję swych wyborów, okazuję się jedynym trwałym punktem odniesienia w potoku znikąd się pojawiających i w nicość powracających widoków, wyzwań, szans, możliwości, pokus, gróźb i recept na życie ${ }^{77}$.

W konsekwencji powoduje to maksymalne zróżnicowanie stylów życia i prowadzi do tego, iż każdy może definiować cel swojej egzystencji w sposób indywidualny. Staje się on - przywołując w tym kontekście koncepcję indywidualizacji - niejako „projektem jednostki"78. W związku z tym wartości, którymi kierujemy się w życiu mogą być dla każdej osoby inne, a poszczególne konteksty współczesnej rzeczywistości mieć różną wagę dla poszczególnych osób. Mamy zatem do czynienia z maksymalną relatywizacją pojęcia szczęścia wśród młodego pokolenia żyjącego w dobie XXI wieku:

Dzisiaj istota szczęścia może być ogrom rzeczy. Dla jednych jest to popularność $w$ social mediach. Im więcej osób obserwujących na różnych portalach, tym większe poczucie i aprobata społeczna. Dla innych szczęście to catkowite odizolowanie się świata mediów. Brak aktywności w szeroko pojętym Internecie i petna prywatność. Dla jednej kobiety spetnieniem marzeń jest urodzenie dziecka, dla innej kariera zawodowa... (Studentka A, specjalność: resocjalizacja)

Jedna osoba wskazała, że odpowiedź na pytanie, czym jest szczęście to odwieczny dylemat egzystencjalny oscylujący pomiędzy dwiema dychotomicznymi wartościami: „mieć czy być”. Zatem mamy tutaj do czynienia z pewnego rodzaju wciąż powtarzającym się problemem natury etycznej i moralnej oraz próbą odpowiedzi na pytanie, co jest w życiu najważniejsze? Fakt posiadania odpowiedniej ilości dóbr materialnych czy życie prawe, w zgodzie z odwiecznymi zasadami i w imię fundamentalnych wartości?

Pojawiła się również odpowiedź, że choć możemy niekiedy kategorię szczęścia postrzegać tak samo, to jednak drogi do jego osiągnięcia mogą być różne (np. bardziej lub mniej etyczne):

Szczęście to stan, do którego każdy stara się dotrzeć. Każdy chce go zaznać. Jednak nikt nie jest w stanie go doznać w identyczny sposób. Kiedyś miałam okazje dyskutować na temat tego, czym dla mnie i moich znajomych ono jest. Teoretycznie niektóre wyznaczniki się powtarzaty, jednak sposoby dażenia do tej konkretnej rzeczy mogą być inne. (Studentka B, specjalność: pedagogika elementarna i język angielski)

77 Z. Bauman, Tożsamość ze sklepu. Tożsamość ze spiżarni, [w:] Kultura popularna i (re)konstrukcje tożsamości, red. A. Gromkowska-Melosik, Poznań - Leszno 2007, s. 50-51.

78 Z. Melosik, Kultura popularna i tożsamość młodzieży, s. 57-59. 
Wśród odpowiedzi respondentów pojawiła się jednak opinia, iż najczęściej ze szczęściem wiążemy fakt posiadania odpowiedniej sumy pieniędzy na koncie (odpowiedziały tak 44 osoby), co z jednej strony umożliwia nam aktywny i satysfakcjonujący udział w życiu społecznym (korzystanie z różnorodnych form rozrywki, aktywności, praktyk kulturowych), z drugiej jednak mogą stać się one pomocne w pokonywaniu codziennych przeciwności i stanowić środek do walki o inne wartości, jak na przykład zdrowie (prywatne leczenie jest co prawda kosztowne, jednak niekiedy bardziej skuteczne i pozbawione wielomiesięcznych oczekiwań na termin swojej wizyty). Przekonanie o tym, iż pieniądze mogą dać nam szczęście stanowi potwierdzenie funkcjonowania współczesnych nastolatków w świecie konsumpcyjnym, w którym wartość jednostki mierzona jest poprzez fakt posiadania wielu znaczących dóbr, które mogą dookreślać jej miejsce w hierarchii społecznej i uprawomocniać jej członkostwo w społeczeństwie ${ }^{79}$. Dlatego też nie dziwi to, iż wśród wypowiedzi dotyczących tego, czym jest współcześnie rozumiane szczęście pojawiły się odpowiedzi, iż jest to nic innego, jak posiadanie modnych, atrakcyjnych współcześnie i wskazujących na odpowiedni - wysoki - status społeczny dóbr materialnych, zgodnych z najnowszymi trendami (wskazało na to 29 osób) czy też posiadanie odpowiednio dużego majątku, który zapewni „godne życie” (2 odpowiedzi):

Moim zdaniem dzisiejsze szczęście jest to posiadanie najnowszych trendów, gadżetów oraz bycie jak najlepszym. Najnowsze ubrania, posiadane pieniądze oraz poczucie bycia lepszym. Posiadając pieniądze ludzie potrafią sobie kupić "szczęście”. (Studentka C, specjalność: wychowanie przedszkolne i nauczanie początkowe)

Patrzac na społeczeństwo $i$ [to - E.G.], czym kieruja się ludzie w dzisiejszych czasach, szczęście to pieniądze, prestiż i uznanie u znajomych. Z mojego punktu widzenia i dla mnie, najważniejszym aspektem szczęścia jest mitość, zdrowie i wsparcie od drugiej osoby. Uważam, że chęć zdobycia pieniędzy także wiąże się ze szczęściem, gdyż w dzisiejszym świecie chcemy mieć $i$ posiadać więcej i więcej. (Studentka D, specjalność: wychowanie przedszkolne i nauczanie początkowe)

Tak rozumiane szczęście, które koresponduje z ideą konsumpcyjnego życia, to nic innego jak zaspokajanie swoich indywidualnych, niekiedy hedonistycznych potrzeb (3 wypowiedzi), co związane jest $\mathrm{z}$ dążeniem $\mathrm{w}$ życiu do przyjemności i maksymalizacją pozytywnych wrażeń (na co wskazało 8 osób). Respondenci uważają, że szczęście jest równoznaczne z posiadaniem odpowiedniego statusu społeczno-ekonomicznego (6 wypowiedzi). Nie dziwi więc, iż część studentów utożsamia współcześnie rozumiane szczęście

\footnotetext{
${ }^{79}$ Z. Bauman, Konsumowanie życia, s. 62-65.
} 
z poczuciem prestiżu i społecznego uznania (13 odpowiedzi), które wydaje się dziś niezwykle znaczące. Potwierdzeniem tego są rozważania Mirosławy Nowak-Dziemianowicz dotyczące współczesnej rzeczywistości, która zwraca uwage, iż walka o społeczne uznanie stanowi jeden $\mathrm{z}$ fundamentalnych zadań i celów XXI wieku ${ }^{80}$. Uważa, iż uznanie

traktowane jest (...) jako najpełniejszy przejaw społecznego charakteru naszego „bycia w świecie". Pokazuje, iż bez drugiego człowieka nie istniejemy, nie możemy się rozwijać, realizować, normalnie funkcjonować. W każdym momencie naszego życia przyglądamy się w oczach innych ludzi, w oparciu o ich opinie budujemy poczucie własnej wartości, ich oczekiwania wyznaczają często ścieżki naszych decyzji ${ }^{81}$.

Studenci odnosząc się do kwestii społecznego znaczenia i prestiżu zwracają również uwagę na istotę aktywności w mediach, liczbę posiadanych „lików”, popularność i obecność na modnych współcześnie portalach społecznościowych. Potwierdza to z kolei silny związek współczesnego młodego pokolenia ze światem wirtualnym i życie w kulturze upozorowania, która wiąże się z równoległym funkcjonowaniem $\mathrm{w}$ obu przestrzeniach ${ }^{82}$.

Trzy osoby uznały, że szczęście w XXI wieku to nic innego, jak bycie osobą sławną lub też posiadanie odpowiedniego atrakcyjnego współcześnie wizerunku (ładny i modny wygląd, który będzie uznany i ceniony przez innych) - odpowiedziały tak 2 osoby. Może to wskazywać na łączenie szeroko rozumianego szczęścia z atrakcyjnością fizyczną, co może stanowić swoistą odpowiedź na zmiany w zakresie współczesnego rozumienia tożsamości i jej kreowania, która to w kulturze współczesnej jest „przenoszona na powierzchnię" $\mathrm{i}$ „uosabiana przez wizualne reprezentacje ${ }^{83 "}$. Mamy tutaj do czynienia ze swoistą "orientacją na wizualność" 84 współczesnego młodego pokolenia, co również staje się elementem walki o szeroko rozumiane uznanie i prestiż społeczny ${ }^{85}$ :

Wszystko zależy od indywidualnego podejścia, choć dzisiejsze młode pokolenie ulega silnym wptywom społeczeństwa i mediów. jest to społeczeństwo, które ulega nieustannej konsumpcji, podążamy za wszystkim, co nowe, wszystkim, co modne.

${ }^{80}$ M. Nowak-Dziemianowicz, Walka o uznanie w narracjach. Jednostka i wspólnota w procesie poszukiwania tożsamości, Wrocław 2016, s. 114.

${ }^{81}$ M. Nowak-Dziemianowicz, Koncepcje uznania w perspektywie pedagogiki ogólnej jako alternatywa wobec neoliberalnej wizji wspótczesnego świata, Forum Pedagogiczne, 2018, 1, s. 173.

82 Z. Melosik, Kultura upozorowania, s. 76-78.

83 Z. Melosik, Tożsamość, ciało i władza, s. 72.

84 A. Gromkowska, Kobiecość w kulturze globalnej. Rekonstrukcje i reprezentacje, Poznań 2002, s. 95-97.

${ }^{85}$ J. Femiak, P. Rymarczyk, Ciało jako temat narracji kultury masowej i narracji wewnętrznej, Rozprawy Naukowe AWF w Poznaniu, 2015, 49, s. 29. 
Każdy chce mieć najnowszy telefon czy chociażby buty, które sa na topie. Dochodzi do zatracenia indywidualności, każdy z nas chce być inny, wyjatkowy, ale przez to wszyscy stajemy się tacy sami, ulegamy temu wszystkiemu, zatracamy własną odrębność. (Studentka D)

Studenci wskazują również na to, iż szczęście to bycie jak najlepszym, poczucie wyższości, bycia lepszym od innych (7 osób), co również związane jest z kulturą konsumpcyjną, jak również uczestnictwem w atrakcyjnych współcześnie formach kultury ( $\mathrm{w}$ tym $\mathrm{w}$ „wysokich praktykach kulturowych” w ramach kultury popularnej $\left.{ }^{86}\right)$, które będą stanowiły potwierdzenie posiadanego statusu i swoisty wyznacznik prestiżu (2 wypowiedzi). Dla niektórych studentów szczęście to po prostu możliwość podróżowania (4 wypowiedzi) - najczęściej wskazują na podróże zagraniczne i zwiedzanie najdalszych zakątków świata - lub po prostu "podążanie za tym, co nowe i nieznane" (1 odpowiedź).

Kolejny wymiar rozumienia szczęścia wyznacza kategoria związana z pracą i karierą zawodową. Okazuje się, iż dla 28 osób szczęście to spełnienie zawodowe, kariera i szeroko rozumiany sukces w tym zakresie. Wskazują przy tym na trudności dotyczące znalezienia odpowiedniej pracy (na miarę swoich możliwości) oraz wysoką konkurencyjność na rynku pracy:

Uważam, że dobry zawód i czerpanie radości z pracy, ponieważ w tych czasach nie jest tak łatwo znaleźć satysfakcjonująca prace, bo konkurencja jest wysoka (Studentka E).

Jednak sam fakt posiadania pracy nie jest wystarczającym wyznacznikiem szczęścia - 12 osób wskazuje, iż szczęście to dobrze płatna praca, która pozwoli na "niezależność” - głównie tę finansową (6 odpowiedzi). Owa niezależność jest dla tych studentów prawdziwym synonimem szczęścia i okazuje się, iż jest dla nich bardzo ważna w życiu:

Uważam, że szczęściem samym w sobie, do którego dąża młodzi ludzie jest uniezależnienie się od rodziców finansowo, bytowo. Dla mnie bardzo istotnym jest bycie niezależnym, pracowanie na własny rachunek pomimo tego, że bardzo cenię moich rodziców. (Studentka F)

Inny kontekst rozumienia szczęścia wyznaczają odpowiedzi związane z samorozwojem i poczuciem satysfakcji z własnego życia. Dla 34 studentów szczęście to nic innego, jak realizacja zamierzonych celów i/lub spełnianie marzeń "poczucie, że osiagnęłam to, co zaplanowałam”. Dla 24 osób synonimem

${ }^{86}$ Z. Melosik, Kultura popularna i tożsamość młodzieży, s. 48. 
tego pojęcia jest podążanie w życiu za zainteresowaniami, „robienie tego, co się lubi" oraz możliwość samorealizacji. Ostatnie pojęcie pojawiło się wielokrotnie w tle wielu innych odpowiedzi (17), które wiązały szczęście z mądrością/ wiedzą, osobistym rozwojem (studenci wymieniali w tym kontekście: samodoskonalenie się, uczestnictwo w kursach, dostępność książek, posiadanie kwalifikacji, fakt, iż mogą studiować lub też posiadanie „dyplomu ukończenia studiów”). Jedna osoba wskazała wręcz, że w jej rozumieniu szczęście to po prostu "dobra książka (i czas na jej przeczytanie)”. Z kolei trzy osoby utożsamiają szczęście z wolnością, w tym wolnością w podejmowaniu wyborów:

W dzisiejszych czasach szczęście daje nam mnogość opcji. Ludzie dąża do tego, by mieć wiele wyborów w życiu, do tego, by nie musieć zamykać się w klatce jednego zawodu, czy też jednej pasji. Dziś szczęściem jest wolność - wolność wyboru. Każdy chce móc decydować o osobie samym i robić co tylko chce i jak chce. Człowiek dziś stawia na konsumpcjonizm i na indywidualność, która da mu satysfakcje życiowa. (Studentka G)

Moim zdaniem każdy inaczej postrzega szczęście, choć mam wrażenie, że dla wszystkich szczęściem jest bycie wolnym. Nie zastanawiamy się nad tym, ale przez wolność możemy być szczęśliwi. Dla mnie bycie wolnym, to przede wszystkim niezależnym. Jeśli sama zapracuję na coś, coś osiąnę, wówczas czuje szczęście, spetnienie. Bycie w relacji z druga osoba, ale kiedy czujemy sie jednocześnie wolni, to też jest rodzaj szczęścia. (Studentka H, specjalność: edukacja elementarna i terapia pedagogiczna)

Okazuje się zatem, że współcześni młodzi ludzie żywią pragnienie realizowania swojej indywidualnej ścieżki życiowej zgodnie z własnymi marzeniami, planami oraz według własnego projektu, co po raz kolejny potwierdza przywołaną już koncepcję indywidualizacji. Niezwykle ważny jest dla nich indywidualny rozwój i stałe podnoszenie przysłowiowej poprzeczki, co również wskazuje na rosnące ambicje współczesnego młodego pokolenia. Zauważają wartość samodoskonalenia i podnoszenia kwalifikacji, co świadczy o rosnących aspiracjach kolejnych pokolen, potwierdza ich pragmatyzm, jak również dobrze rokuje na przyszłość.

Moim zdaniem źródłem szczęścia nie jest z pewnością ilość przedmiotów jakie w swoim życiu posiadaliśmy. Szczęście rozumiem jako możliwość spetnienia się w swoich pasjach, rozumienia siebie, umiejętność określenia własnego „ja" w świecie. Biorac pod uwage zmienność wspótczesnego świata, trendów jakie obowiąuja, myślę, że jest to trudne zadanie, by jakoś się w nim odnaleźć. Dlatego powiedziałabym, że człowiek szczéśliwy to taki, który wie, do czego w życiu dąży, ma jasno określone 
cele i przede wszystkim potrafi myśleć samodzielnie. Ostatnie uważam za kluczowe, ponieważ ilość informacji, zapewnień ze strony innych ludzi, jakie do nas naptywaja, jest tak duża, że jesteśmy zmuszeni filtrować te informacje i wybierać oraz przyswajać te, które uważamy za istotne, właściwe. (Studentka I, specjalność: doradztwo zawodowe i personalne)

Mnie osobiście poczucie szczęścia daja osoby, którymi się otaczam oraz po prostu to, w jakim miejscu w świecie się aktualnie znajduję. Od 14 roku życia, podczas obchodzenia urodzin $i$ dmuchania w świeczki, prosiłam, aby być szczéśliwa. Jutro mam swoje 21 urodziny i już nie muszę tego sobie życzyć. Ba, już rok temu nie musiałam. Odnalazłam miłość, studiuję coś, co mnie interesuje, rozwija, coś, co uwielbiam. Spetniam się artystycznie, teatralnie i muzycznie, o czym zawsze marzyłam, a dodatkowo spetniam marzenie, jakim było posiadanie królika. Moge definitywnie powiedzieć, że właśnie tak wyglada moja definicja szczęścia. (Studentka J, specjalność: edukacja elementarna i terapia pedagogiczna)

Pojawiły się liczne stwierdzenia, iż szczęście to nic innego, jak posiadanie rodziny i grona przyjaciół (wskazało na to 37 osób). Pięć osób uznało też za największe szczęście stworzenie rodziny i urodzenie dziecka. Inni (13 osób) docenili wspólny czas spędzony z bliskimi - rodziną i przyjaciółmi (,ludźmi, których kocham") - uznając go za najwyższy wymiar szczęścia (13 odpowiedzi). Może to stanowić odpowiedź na fastfoodyzację relacji międzyludzkich ${ }^{87}$, co obserwujemy współcześnie i zarazem próbę wyrażenia tęsknoty za prawdziwym, a nie tylko powierzchownym, krótkotrwałym kontaktem z drugim człowiekiem.

Powiedzieć można, że szczęście, poczucie spetnienia dokona się poprzez dobrą prace, pieniądze czy inny majątek. Nie zwraca sie już uwagi [na to - E.G.], co naprawde jest istotne. Można mieć wszystko, ale czy na pewno? Każdy dzień powinno spędzać się z osoba, która kochamy, ufamy. Teraźniejszość jest inna, cała satysfakcja jest wtedy, [gdy - E.G.] dojdziemy do czegoś, dojdziemy sami, naprawiamy, ulepiamy, a nie wyrzucamy i wymieniamy. Szczęście powinno mieć się z kim dzielić, ale nie na chwile. (Studentka K)

Biorąc pod uwagę analizowaną kategorię, niezwykle ważne dla pytanych okazało się poczucie przynależności oraz akceptacji, jak i świadomość „bycia potrzebnym i kochanym" przez ludzi, na których można liczyć (31 odpowiedzi). Wielokrotnie zwracały one uwagę na wartość posiadania osób, dla których coś znaczą i które są dla nich prawdziwym wsparciem. Osób, z którymi mogą dzielić zarówno te pozytywne, jak i trudne momenty:

${ }^{87}$ Tamże. 
Poczuciem szczęścia nie jest materializm, ponieważ dobra materialne, rzeczowe są dostępne na wyciagnięcie ręki. Najważniejsze jest poczucie akceptacji, świadomość, że nie jest się samemu, że jest się kochanym, szanowanym i posiadanie wspierajacego otoczenia oraz bliskich, na których będziemy mogli polegać zawsze i bezwarunkowo. Celem w życiu jest życie drugiego, najważniejszego dla nas człowieka, jego i nasze szczęście. (Studentka L)

Szczęście wspótcześnie oznacza przynależność do grupy. Przynależność pełna, z poczuciem zrozumienia, zaangażowania w jej życie. Moga to być różne jej rodzaje: rodzina, szkoła, harcerstwo. Wydaje się to być niezrozumiałe biorac pod uwage to, jak rzeczywistość szybko się zmienia i jak płynna jest nasza tożsamość. Jednak to ciagłe dopasowywanie się do otoczenia jest głęboka potrzeba przynależności gdziekolwiek. (Studentka M)

Ostatnie stwierdzenie koresponduje z przywołaną przez Agnieszkę Gromkowską-Melosik kategorią Mimesis, odnoszącą się do „pożądania naśladowczego", charakteryzującego jednostki i gwarantującego przetrwanie naszej kulturze ${ }^{88}$. Staje się ona istotną częścią życia we współczesnym, nieustannie zmieniającym się świecie, w którym, jak twierdzi Z. Mitosek, „absolutna ekspresja kończy się absolutną imitacją: naśladujemy sąsiadów, wrogów, bohaterów powieści, gwiazdy ekranu” ${ }^{89}$. Należy zwrócić uwagę, iż adaptacja mimetyczna nie jest jednoznacznie negatywna i spełnia istotną funkcję o charakterze socjologicznym - stanowi ona warunek funkcjonowania jednostki w grupie, daje szansę na odnalezienie się w większej społeczności oraz poczucie bycia "adekwatnym” i przystającym do współczesnych oczekiwań i wymagań ${ }^{90}$.

Dla pytanych studentów szczęście to również bliskość, obecność drugiego człowieka (wskazało na to 20 osób). Uargumentowywali oni takie rozumienie szczęścia możliwością szczerej i otwartej wymiany poglądów. Bez udawania i zakładania masek. Można odnieść to do współczesnego rozumienia tożsamości zaprezentowanego przez Anetę Ostaszewską, która uważa, iż

dzisiaj tożsamość jest czymś na wzór kreacji, którą w dowolnym momencie wymieni się - niczym ubranie - na inną, bardziej świeżą, atrakcyjniejszą. Jest narcystycznym wizerunkiem stworzonym na potrzeby konkretnego czasu, konkretnej sceny i publiczności; jest maską, którą zawsze można wymienić na inną, maską, przy konstrukcji której podstawowego znaczenia nabierają atrybuty dramaturgiczne i estetyczne. Tożsamość współczesnego człowieka jest więc czymś „na pokaz” i czymś „na teraz”. Jutro bowiem za sprawą mediów i kultury popularnej pojawią się nowe możliwości, nowe

\footnotetext{
88 A. Gromkowska, Kobiecość w kulturze globalnej, s. 20.

89 Z. Mitosek, Mimesis. Zjawisko i problem, Warszawa 1997, s. 15, za: tamże.

90 A. Gromkowska, Kobiecość w kulturze globalnej, s. 20-21.
} 
środki ekspresji oraz nowe wymagania wobec tożsamości. To z kolei rodzi konieczność bycia w stanie ciągłej gotowości do podejmowania (kolejnych) prób autokreacji, a nawet eksperymentowania ze swoją tożsamością ${ }^{11}$.

Można wysunąć wniosek, iż współczesna młodzież niezwykle ceni sobie autentyczność i brak przymusu ciągłego dostosowywania się do wymogów społecznych, „noszenia określonych masek”. Chce być sobą i w tym byciu sobą próbuje odnaleźć kogoś, kto podzieli ich poglądy i przed kim nie będą musieli udawać, starać się, czy gonić za wszystkim tym, co jest tak mocno promowane przez współczesny świat. Pragną otwartej, szczerej relacji, pełnej życzliwości i wzajemnej pomocy.

Współcześnie szczęście daje ludziom to, że nie sa sami, że maja kogoś, do kogo moga się zwrócić, moga porozmawiać - znajomi, przyjaciele. To, że przynależa do jakiejś grupy i moga w niej szukać zrozumienia, wsparcia, pomocy. (Studentka N)

Wedtug mnie istota szczęścia jest akceptowanie przez innych ludzi. Młodym osobom zawsze zależy na opinii innych osób, bo dzięki niej (jeśli będzie pozytywna) moga mieć poczucie przynależności do jakiejś grupy. Moim zdaniem właśnie takie docenianie drugiej osoby a nie ocenianie jest dla młodzieży dużym powodem do szczęścia. (Studentka O)

Istotne dla respondentów okazały się wszelkie kontakty międzyludzkie (również te rozwijane i tworzone za pośrednictwem Internetu, czego potwierdzeniem jest Raport Nastolatki 3.092). Chcą i potrzebują otaczać się ludźmi. Okazuje się, że fakt posiadania znajomych, przyjaciół, osób, na których można liczyć jest dla nich w obecnych czasach bardzo ważny (17 wypowiedzi). Zwracali przy tym uwagę, iż jest to swoiste zabezpieczenie przed samotnością, której nie chcą:

Dla mnie szczęściem jest posiadanie ludzi, których się kocha i którzy kochaja mnie. Myślę, że jak będe to miała, to będę w petni szczęśliwa. Nie wiem, jak myśla inni ludzie, ale mam nadzieję że podobnie (Studentka P, specjalność: edukacja elementarna i nauczanie dzieci z niepełnosprawnością intelektualną w stopniu lekkim)

Dla studentów szczęście to po prostu miłość, przyjaźń lub szeroko rozumiana troska o drugiego człowieka (16 osób). Wskazali, że ich szczęście jest

91 A. Ostaszewska, Popkulturowe ramy tożsamości. Media, kultura popularna, internet jako nowe środowiska kształtowania tożsamości, Warszawa, s. 6, źródło: http://www.bc.ore.edu.pl/Content/666/popkulturowe+ramy+tosamoci.pdf, [dostęp: 20.09.2019].

92 Nastolatki 3.0. Raport z badania, Warszawa 2017, s. 25. 
związane z zadowoleniem i szczęściem innych - „poczucie, że maja wszystko, czego im potrzeba" (3 wypowiedzi). Pojawiła się tutaj kategoria zdrowia (14 odpowiedzi), jednak nie chodzi tylko o zdrowie własne, ale także najbliższych nam osób. Dwie osoby uznały, że szczęście to nic innego, jak możliwość sprawiania innym przyjemności, dzielenie się radością oraz służenie pomocą potrzebującym - „szczęście odnajduje nawet w uśmiechu drugiej osoby” (2 wypowiedzi).

Istota szczęścia jest dla mnie możliwość przebywania wśród ludzi, których kocham, którzy sa dla mnie w pewnym stopniu ważni. Zajmuja takie miejsce w moim życiu, które zwyczajnie nie może pozostać puste, ponieważ nie czułabym się usatysfakcjonowana. Jednakże dopetnieniem zaspokojenia szczęścia w życiu jest możliwość czynienia czegoś dobrego dla drugiej osoby. Po wielu latach obserwacji mogé śmiało powiedzieć, iż takim "paliwem” napędzającym moje życie jest szczęście bliskich mi osób. Kiedy sama moge im pomóc, wywotać uśmiech na ich twarzach, jest to wystarczające, abym sama mogła poczuć się lepiej, szczęśliwym człowiekiem. (Studentka R, specjalność: resocjalizacja)

Studenci wskazują również na to, iż prawdziwe szczęście to poczucie stabilizacji/stabilności w życiu (5 osób), dla innych jest to po prostu poczucie bezpieczeństwa (10 odpowiedzi). Okazuje się zatem, iż życie w płynnej, niepewnej i niestałej rzeczywistości prowokuje do poszukiwania stałości w życiu, poczucia pewności, co w konsekwencji będzie równoznaczne z odczuwaniem bezpieczeństwa. Może to korespondować z wnioskami zawartymi w raporcie zatytułowanym Pokolenie $Z$ w finansach i na rynku pracy, odnoszącymi się do tego, iż

stały dostęp do Internetu oraz możliwości jakie daje, włączenie do codziennego życia korzystania z portali social mediowych, presja na zdobywanie w nich uznania, budowanie wizerunku, cyberprzemoc, większa rola znajomości wirtualnych, a także szereg zmian społecznych, w tym większa liczba rozwodów powodują, że coraz więcej nastolatków nie radzi sobie z problemami i narastającym stresem. Pojawia się problem fonoholizmu, czyli uzależnienia od telefonów i Internetu oraz bardzo niepokojące zjawisko zwiększającej się liczby problemów psychicznych i prób samobójczych wśród nastolatków ${ }^{93}$.

Może to tłumaczyć tak często pojawiające się wśród studentów odpowiedzi dotyczące ważności posiadania rodziny, bliskich osób, które będą stanowiły źródło prawdziwego wsparcia i pomocy oraz poczucie akceptacji i przynależności, a także bycia kochanym, co w konsekwencji może wpłynąć

\footnotetext{
${ }_{93}$ Pokolenie Z w finansach i na rynku pracy. Raport, s. 5.
} 
bezpośrednio na poczucie bezpieczeństwa i pewnego rodzaju poczucia stałości w życiu.

Inny kontekst współcześnie rozumianego szczęścia w opinii moich respondentów wyznacza życie w zgodzie z samym sobą. W pierwszej kolejności warto odnieść się do tego, iż dla części studentów szczęście to akceptacja samego siebie (4 osoby). Studenci zwracali uwagę na to, iż człowiek szczęśliwy to ten, który ma możliwość bycia sobą, jest i czuje się wolny oraz odnalazł w życiu własne „ja” (odpowiedziało tak 12 osób):

Szczęście daje akceptacja siebie, swoich wad $i$ zalet, ponieważ gdy zaakceptujemy siebie, to nikt nie będzie w stanie zburzyć naszego szczęścia, celów, do których dążymy. Szczęście daja też jasno wyznaczone cele w życiu, a dokładniej droga, która do nich zmierzamy. Szczęście dają osoby wokót nas, wybrane przez nas grono przyjaciót i wspierająca rodzina. Szczęście dają też małe rzeczy, bo nie musimy wyjeżdżać, podróżować, spetniać czyichś ambicji, lecz wystarczy dostrzec to, co wokót nas i być świadomym. (Studentka S)

Dla mnie szczęcie jest petna akceptacja siebie, swoich wad $i$ zalet oraz życia w harmonii między tym, czego oczekuję od świata a tym, co świat mi daje. Szczęście daje mi czas spędzony z ludźmi, których kocham oraz własna satysfakcja lub docenianie kogoś innego za odniesiony sukces lub pokonanie jakiejś przeszkody. Moim zdaniem, szczéście jest dla ludzi posiadaniem czegoś atrakcyjnego oraz wysoki status materialny. Myślę, że dla wielu ludzi szczéście wiąze się z byciem w zwiazku oraz ich popularnością. (Studentka T, specjalność: wychowanie przedszkolne i nauczanie początkowe)

W tym ujęciu szczęście to również troska o ciało i zdrowie psychiczne (4 wypowiedzi). Nie chodzi tu jednak o konsumpcyjny wymiar szczęścia, ale o asertywną postawę, zgodną z naszymi przekonaniami i wartościami:

Umiejętność mówienia 'Nie' w sytuacjach, które nam się nie podobaja, umiejętność proszenia o pomoc, pozwolenia sobie na płacz, kiedy jest nam smutno (Studentka U, specjalność: wychowanie przedszkolne i nauczanie początkowe).

Dwie osoby uznały, że szczęście to po prostu życie w zgodzie i prawdzie (z prawdziwymi i szczerymi osobami obok):

Moim zdaniem szczęście takie tymczasowe daja nam różne materialne rzeczy, jak $n p$. nowe ubrania, nowy telefon itp. Ale to najważniejsze szczęście dla mnie jest życie w zgodzie i prawdzie. Wielkie szczęście daje mi rodzina, której nie sprzedałabym za żadne skarby. Bo to ona kocha mnie bezwarunkowo. Szczęście daje mi także świado- 
mość życia wiecznego. Że życie nie kończy się na tym, co ziemskie. Podsumowując, największa radość daje mi rodzina i ludzie, którzy mnie otaczają. (Studentka W)

Dla innych osób to wewnętrzny spokój (2 osoby) lub kontakty z naturą w celu osiągnięcia spokoju i wyciszenia (2 osoby), jak również wiara (2 osoby). Odpowiedzi te można odnieść do poszukiwania równowagi i harmonii w życiu, funkcjonowania w zgodzie z fundamentalnymi wartościami, takimi jak dobro, prawda i piękno. Jak również relacji z Bogiem, na którym mogą się oprzeć.

Pytani przeze mnie studenci zdają sobie sprawę z przemian współczesnej rzeczywistości i z łatwością dostrzegają wartości prezentowane przez konsumpcyjny świat, które niejednokrotnie stają się celem i fundamentem dla ich życia oraz życia ich rówieśników. Są świadomi rosnącego egocentryzmu i egoizmu nastolatków, którzy skupiają się głównie na realizowaniu własnych pragnień i poszukiwaniu przyjemności, co jednak nie przynosi prawdziwej satysfakcji (która „w pełni nastąpić nie może” ${ }^{94}$ ), radości i szeroko rozumianego szczęścia oraz jest paralelne do charakterystyki społeczeństwa narcystycznego Ch. Lascha95. Dowodzi również o życiu w spirali niekończących się wyborów konsumpcyjnych dających jedynie pozorne i tylko chwilowe szczęście, o czym pisał w kontekście schizofreniczności kultury konsumpcji Z. Melosik ${ }^{96}$. Potwierdzeniem tego są przykładowe wypowiedzi studentów:

Niestety, coraz częściej młodzi ludzie nie potrafią dostrzegać tego, co ważne. Nie potrafia odnaleźć swojego celu $i$ "gonią" za tym, co świat oferuje - fatszywe wartości, puste i nic niewnoszace szczéście. Społeczeństwo jest hedonistyczne i na pierwszym miejscu przedkłada zaspokajanie swoich potrzeb, nawet kosztem innych i siebie - w złych wyborach. Widać to często po samotności i problemach, z którymi borykaja się ludzie (Studentka V)

Moim zdaniem szczęście jest czymś rzadkim w dzisiejszych czasach, ponieważ jest ono tak naprawdę czymś ulotnym, przyjemnym uczuciem, które ma swoje ograniczenie czasowe. Osiagamy jakiś cel, który sobie wyznaczyliśmy i okazuje się, że po jego osiagnięciu czujemy niedosyt $i$ chcielibyśmy więcej. Z jednej strony jest to pozytywne pod wzgledem naszego rozwoju, np. zrobiliśmy kurs trenera personalnego, ale czujemy, że nasza wiedza nie jest jeszcze wystarczająca, żeby dobrze wykorzystać ten zawód, więc szkolimy się dalej zapisując się na jakieśs szkolenia. Z drugiej strony jest to negatywne, ponieważ, gdy dążymy do jakiegoś celu, np. kupienie wymarzonego telefonu i w końcu go kupujemy, jesteśmy zadowoleni z naszych wysiłków, które do-

\footnotetext{
94 Z. Melosik, Ponowoczesny świat konsumpcji, s. 72.

95 Ch. Lasch, Kultura narcyzmu, s. 12-34.

96 Z. Melosik, Ponowoczesny świat konsumpcji, s. 72.
} 
prowadzity nas do osiagnięcia tego celu i postanawiamy, że stać nas na więcej i zbieramy pieniądze na nowy model telefonu, nawet jeśli on się nie różni od poprzedniego, którego chcieliśmy (Studentka X, specjalność: edukacja elementarna i język angielski)

Można odnieść wrażenie, że coraz częściej mają oni świadomość, że szczęście ofiarowane przez konsumpcyjny świat jest tylko pozorne, a to co faktycznie ważne niejednokrotnie pozostaje ukryte i często niewidoczne dla młodego pokolenia. Zauważają przy tym odwieczne wartości, doceniają posiadanie rodziny, grona przyjaciół i wsparcie pochodzące od bliskich osób, do czego wielokrotnie się odwołują:

Myśle, że ptynna tożsamość $i$ egzystencja ani konsumpcjonizm nie może dać szczęścia. Daje je to, co bardziej trwałe: rodzina, przyjaciele, poważnie traktowane decyzje i wartości. (Studentka Y, specjalność: edukacja elementarna i nauczanie dzieci z niepełnosprawnością intelektualną w stopniu lekkim)

$W$ dzisiejszym świecie wg mnie szczẹście jest pozorne. Przez życie w ciąłtym biegu ludzie szukają tego, co wydaje im się, że daje im to szczęście. Większość osób uważa, że jeśli będzie miała pieniądze, to dzięki nim zapewni sobie wszystko, co potrzebne do tego, by być szczęśliwym, a tak naprawdę wedtug mojej osoby dzięki temu straci możliwość na bycie szczęśliwym. Dla mnie szczęście to mieć przy sobie bliska osobę, która kocha i wspiera i nie pozwala upaść w najgorszych chwilach. (Studentka Z)

Szczęście w życiu, w dzisiejszych czasach daje awans zawodowy $i$ społeczny. Im więcej ktoś ma pieniędzy, tym może na więcej sobie pozwolić. Jednak moim zdaniem to jest bez sensu na dłuższa metę, bo pieniądze kiedyś się skończą. Szczęściem powinni być ludzie, którzy sa z nami na dobre i złe. W dzisiejszych czasach mało kto o tym pamięta. (Studentka \&)

W myśl przywołanych wyżej stwierdzeń, argumentów, jak również udzielonych przez studentów odpowiedzi można uznać, iż żyjemy w świecie skonstruowanym $\mathrm{z}$ wielu, czasami sprzecznych, wizji tego, czym $\mathrm{w}$ istocie jest szczęście. Sfragmentaryzowanie, efemeryczność i niestałość współczesnej kultury oraz naszych tożsamości, jak również wizji rzeczywistości (na co składają się przywołane we wstępie zjawiska i procesy) staje się nie tylko teorią, ale realną częścią egzystencji w dobie XXI wieku ${ }^{97}$, co można zauważyć $\mathrm{w}$ wielu obszarach naszego życia, nawet podczas poszukiwania odpowiedzi na pytanie, czym w istocie jest szczęście. Odnosząc się do pokolenia Z i jego sposobu patrzenia na świat, być może trafnym podsumowaniem i zarazem

${ }^{97}$ A. Gromkowska, Kobiecość w kulturze globalnej, s. 98. 
punktem wyjścia do próby sformułowania jakichkolwiek wniosków w tym wymiarze będą słowa Franza Falangi, który pisał następująco:

Tym wszystkim, którzy mówią, że dzisiejsza młodzież bardzo różni się od nas, odpowiadam, że wcale tak nie jest. Dzisiejsi młodzi są zasadniczo bardzo do nas podobni (...). Jeśli na pierwszy rzut oka wydają się inni od nas, to dlatego, że są stworzeni na obraz i podobieństwo współczesnego społeczeństwa, ale w głębi wcale się nie zmienili. Wystarczy tylko wiedzieć, jak być z nimi, jak rozumieć ich lęki i słabości, ich przerażającą samotność i ich plany ${ }^{98}$.

Uzyskane odpowiedzi dają zatem nadzieję, że pojmowane przez przedstawicieli młodego pokolenia szczęście, choć tak różne (biorąc pod uwagę poszczególne wypowiedzi), jest jednak w dużej mierze związane z wartościami (również ponadczasowymi) przypisywanymi ludziom i przez ludzi od pokoleń, a nie, w sposób bezpośredni, ze specyfiką określonych, pojawiających się kolejno generacji i z właściwymi wyłącznie dla nich cechami. Wydaje się zatem, że samo pojęcie szczęścia jest czymś ponadczasowym i ponadwymiarowym, które łączy - nie tyle horyzontalnie, ale przede wszystkim w dużej mierze wertykalnie - poszczególne pokolenia.

\section{Podsumowanie}

Kategoria szczęścia jest bezsprzecznie kwestią zróżnicowaną, zrelatywizowaną i maksymalnie zindywidualizowaną. Jak już wielokrotnie wspomniano, dla każdego szczęście może być czymś innym. Biorąc jednak pod uwagę wpływy zewnętrzne, przeobrażenia kultury, proces globalizacji, zmienność świata oraz fakt życia w płynnej i sfragmentaryzowanej rzeczywistości o charakterze konsumpcyjnym, zdarza się, że zamiast poszukiwać indywidualnej ścieżki życiowej i odwoływać do tych tradycyjnych, a więc sprawdzonych wartości, które miałyby na tej drodze obowiązywać, młode pokolenie woli szybsze (nawiązując do życia w natychmiastowości i wspomnianych już kategorii „fast" $\left.{ }^{\prime \prime 9}\right)$ i z pozoru bardziej atrakcyjne rozwiązania proponowane przez popkulturowy świat. Jak stwierdził jeden z respondentów: Wszystkie wymienione rzeczy łącza się z tym, że w wyniku globalizacji, stylów życia narzucanych nam przez media, młode osoby podążają w kierunku wyznaczonym przez innych, zatracając przy tym własna autentyczność. (Student @).

${ }_{98}$ F. Falanga, A propostio della comunicazione. Come perdere con assoluta certezza le elezioni, Armando, Roma 2009, s. 99; za: M. Szcześniak, G. Rondón, Pokolenie „ani-ani”: o młodzieży, która się nie uczy, nie pracuje i nie dba o samokształcenie, Psychologia Społeczna, 2011, 6, 3(18), s. 241.

99 Z. Melosik, Edukacja, młodzież i kultura wspótczesna, s. 21. 
Można wysunąć wniosek, iż w miarę upływu czasu kategoria szczęścia będzie ulegać dalszej maksymalnej relatywizacji i w dalszym ciągu - być może coraz trudniejszy (w dobie rosnącej rywalizacji, konkurencyjności, życia w świecie konsumpcji, kulturze obrazkowej, kulturze klikania oraz czasach, kiedy tak wielką wartość przypisuje się posiadanemu statusowi, nieograniczonej wolności związanej z bezkresnym urzeczywistnianiem indywidualnych marzeń, hedonizmowi i społecznemu znaczeniu) - będzie obecny i już dziś zauważalny dylemat na linii wartości materialne i niematerialne. I towarzyszyć nam będzie coraz bardziej retoryczne, bo już teraz niejednokrotnie nierozwiązywalne, pytanie „mieć czy być?”, na które wydawać by się mogło coraz trudniej (także w wymiarze jednostkowym) znaleźć jakąkolwiek odpowiedź.

Pomijając indywidualne przekonania jednostek, a zarazem zauważając i doceniając fakt, iż - co już zostało wspomniane - wśród młodego pokolenia jest grono osób, które jednak szuka w życiu równowagi i docenia tradycyjne wartości, pragnę zaryzykować stwierdzenie, że eudajmonizm w dobie pokolenia Z można uznać za nic innego jak swoistego rodzaju „wyzwanie jutra”, oznaczające poszukiwanie, a w konsekwencji odnalezienie w życiu autentyczności. To bycie prawdziwym oraz wymaganie tej prawdy od innych. W świecie, w którym „wszystko miesza się ze wszystkim” wydawać by się mogło, że życie w zgodzie ze sobą, w prawdzie i poczucie bycia autentycznym może być uznane za prawdziwe szczęście będące ponad konsumpcyjnymi marzeniami osób nas otaczających czy ponadnarodowych korporacji, które skutecznie pozwalają zachęcić nas do życia w określony sposób bądź też (używając rozlicznych środków perswazji) manipulować nami, osiągając swoje komercyjne cele. To prawdziwe wyzwanie dla nastolatków i wchodzących w dorosłość osób, którym przyszło żyć „,w najlepszym z możliwych światów”, , „jedynym do pomyślenia"100 $\mathrm{w}$ świecie niekończącej się przyjemności ${ }^{101}$. To równowaga pomiędzy prawdą i fałszem, to poszukiwanie tej pierwszej w życiu, rezygnując z pozornego i pięknie opakowanego w popkulturowe hasła supermarketu towarów, które możemy w sposób dowolny gromadzić, kolekcjonować i za wszelką cenę mnożyć.

Podsumowaniem tego artykułu niech staną się słowa Roberta Spaemanna, który pisał następująco:

Uznanie subiektywnej przyjemności za ostateczny cel, o który zawsze chodzi lub powinno chodzić działającemu, oznacza świadomą rezygnację z intencjonalności, ze skierowania naszych stanów psychicznych na coś poza nimi, z konstytutywnej dla nich „autotranscendencji”. Człowiek jest z natury istotą, która nie pojmuje siebie na-

${ }_{100}$ Z. Melosik, Ponowoczesny świat konsumpcji, s. 72.

101 Z. Melosik, Postmodernistyczne kontrowersje wokót edukacji, s. 196. 
turalistycznie, lecz której „chodzi o coś” - o coś, czego nie może rozumieć jako funkcji własnych stanów zadowolenia lub niezadowolenia ${ }^{102}$.

Dlatego, szukajmy w życiu „czegoś więcej”, istoty nas, naszego życia i nie zrażając się tym, że możemy spotkać się z niezrozumieniem, szukajmy prawdy, prawdziwych wartości i prawdziwego sensu naszego funkcjonowania w świecie oraz zachęcajmy do tego kolejne młode pokolenia. W końcu, cytując zasłyszane niegdyś słowa Stanisława Jerzego Leca: „By dojść do źródła, trzeba płynąć pod prąd”. I nie po to, by osiągnąć tak aprobowany współcześnie prestiż, sukces, czy społeczny poklask, ale by odnaleźć autentyczność, spełnienie i prawdziwą (dla siebie) wartość na swojej zindywidualizowanej życiowej ścieżce. I choć prawda może być dla każdego inna, to jednak może stanowić ważki i ważny współcześnie klucz do szeroko rozumianego szczęścia.

\section{BIBLIOGRAFIA}

A generation without borders. Embracing Generation Z, OC\&C, 2019, źródło: https:/ / www.occstrategy.com/media/1806/a-generation-without-borders.pdf, [dostęp: 20.09.2019].

Babbie E., Podstawy badań społecznych, Wydawnictwo Naukowe PWN, Warszawa 2008.

Baudrillard J., Selected Writings, red. M. Poster, Polity Press, Cambridge 1988.

Bauman Z., O miejscu teatru w ponowoczesnej sztuce, [w:] Teatr w miejscach nieteatralnych, red. J. Tyszka, Wydawnictwo Fundacji Humaniora, Poznań 1998.

Bauman Z., Nowoczesność i ponowoczesność, [w:] Encyklopedia socjologiczna, t. II, Wydawnictwo Naukowe PWN, Warszawa 1999.

Bauman Z., Globalizacja, Państwowy Instytut Wydawniczy, Warszawa 2000.

Bauman Z., Płynna nowoczesność, Wydawnictwo Literackie, Kraków 2006.

Bauman Z., Ptynne życie, Wydawnictwo Literackie, Kraków 2007.

Bauman Z., Tożsamość ze sklepu. Tożsamość ze spiżarni, [w:] Kultura popularna i (re)konstrukcje tożsamości, red. A. Gromkowska-Melosik, Wyższa Szkoła Humanistyczna w Lesznie, Poznań - Leszno 2007.

Bauman Z., Konsumowanie życia, Wydawnictwo Uniwersytetu Jagiellońskiego, Kraków 2009.

Bauman Z., 44 listy ze świata płynnej nowoczesności, Wydawnictwo Literackie, Kraków 2011.

Beck U., Społeczeństwo ryzyka. W drodze do innej nowoczesności, Wydawnictwo Naukowe Scholar, Warszawa 2004.

Bogaj A., Konsekwencje procesu globalizacji dla edukacji, [w:] Edukacyjne problemy czasu globalizacji, red. A. Karpińska, Trans Humana, Białystok 2003.

Borkowski R., Globalizacja, cywilizacja, ponowoczesność, [w:] Globalopolis. Kosmiczna wioska szanse i zagrożenia, Instytut Wydawniczy PAX, Warszawa 2003.

Bujacz A., Hornowska E., Hedonizm i eudajmonizm w badaniach psychologii pozytywnej, Psychologia Jakości Życia, 2012, 11, 1.

Denzin K.N., Lincoln S.Y., Metody badań jakościowych, Wydawnictwo Naukowe PWN, Warszawa 2009.

102 R. Spaemann, Szczęście a życzliwoość. Eseje o etyce, Lublin 1997, s. 51. 
Desjardins J., Meet Generation Z: The Newest Member to the Workforce, źródło: https:/ / www. visualcapitalist.com/meet-generation-z-the-newest-member-to-the-workforce/, [dostęp: 20.09.2019].

Dolot A., The characteristic of Generation Z, e-mentor, 2018, s. 44-50, http://dx.doi. org/ 10.15219/em74.1351.

Encyklopedia popularna PWN, Wydawnictwo Naukowe PWN, Warszawa 1997-2019.

Falanga F., A propostio della comunicazione. Come perdere con assoluta certezza le elezioni, Armando, Roma 2009.

Femiak J., Rymarczyk P., Ciało jako temat narracji kultury masowej i narracji wewnętrznej, Rozprawy Naukowe AWF w Poznaniu, 2015, 49.

Francis T., Hoefel F., 'True Gen': Generation Z and its implications for companies, źródło: https://www.mckinsey.com/industries/consumer-packaged-goods/our-insights/ true-gen-generation-z-and-its-implications-for-companies, [dostęp: 15.09.2019].

Frankl V., Paradoksy szczęścia, Życie i Myśl, 1977, 1.

Generation Z Looks a Lot Like Millennials on Key Social and Political Issues, Pew Research Center, January 2019.

Giddens A., Nowoczesność i tożsamość. "Ja" i społeczeństwo w epoce późnej nowoczesności, Wydawnictwo Naukowe PWN, Warszawa 2001.

Gmerek T., Dyskursy męskości w reklamie wspótczesnej, [w:] Kultura popularna i (re)konstrukcje tożsamości, red. A. Gromkowska-Melosik, Wyższa Szkoła Humanistyczna w Lesznie, Poznań - Leszno 2007.

Gromkowska A., Kobiecość w kulturze globalnej. Rekonstrukcje i reprezentacje, Wolumin, Poznań 2002.

Gromkowska-Melosik A., Stratyfikacja, ruchliwość społeczna, edukacja - kilka uwag teoretycznych, [w:] Edukacja i stratyfikacja społeczna, red. T. Gmerek, Wydawnictwo Naukowe UAM, Poznań 2003.

Grupa Wirtualna Polska, Pokolenie Z - nie warto bronić im dostępu do nowych technologii, źródło: „dzieci.pl”, [dostęp: 15.07.2019].

Half R., Get ready for Generation Z, 2015, źródło: http:/ / www.ncfef.com/resources/Presentations/2017_Events/GenZ.pdf, [dostęp: 20.09.2019].

Iwasiński Ł, Społeczeństwo konsumpcyjne w ujęciu Zygmunta Baumana, Kultura i Społeczeństwo, 2015, 4 .

Ipsos Thinks. Beyond Binary. The lives and choices of Generation Z, źródło: https:/ / www.ipsos. com/sites/default/files/2018-08/ipsos_-_beyond_binary_-_the_lives_and_choices_ of_gen_z.pdf, [dostęp: 15.09.2019].

Iyer P., The Global Village Finally Arives, „Times”, Social Issue, Fall, 1993.

Jak zrozumieć dziś pokolenie jutra. Raport - wersja demo, red. M. Jungiewicz, Infuture Hatalska Foresight Institute, Gańsk - Warszawa 2019.

Kleinschmit M., Generation Z Characteristics: 5 Infographics on the Gen Z Lifestyle, źródło: https://www.visioncritical.com/blog/generation-z-infographics, [dostęp: 15.09.2019].

Kostyńska M., Pokolenie Z, czyli pokolenie nowoczesnych technologii i Internetu, źródło: https:/ / msp.money.pl/wiadomosci/poradniki/artykul/pokolenie-z-czyli-pokolenienowoczesnych,81,0,2419537.html, [dostęp: 15.07.2019].

Kotler P., Marketing 4.0, Wiley, New Jersey 2017.

Krippendorff K., Content analysis. An introduction to its methodology, Sage, Thousand Oaks 2004.

Langdridge D., Introduction to research methods and data analysis in psychology, Open University Press, Buckingham 2004.

Lasch Ch., Kultura narcyzmu, Wydawnictwo Sedno, Warszawa 2015. 
Lisowska-Magdziarz M., Analiza zawartości mediów. Przewodnik dla studentów, Wydawnictwo Uniwersytetu Jagiellońskiego, Kraków2004.

Majerek B., Młody prekariat, czyli codzienna niepewność, [w:] Codzienność jako wyzwanie edukacyjne, Instytut Pedagogiki Uniwersytetu Wrocławskiego, Wrocław 2017.

Melosik Z., Postmodernistyczne kontrowersje wokół edukacji, Wydawnictwo Edytor, Poznań - Toruń 1995.

Melosik Z., Tożsamość, ciało i wtadza. Teksty kulturowe jako (kon)teksty pedagogiczne, Wydawnictwo Edytor, Poznań - Torun 1996.

Melosik Z., Ponowoczesny świat konsumpcji, [w:] Ciało i zdrowie w społeczeństwie konsumpcji, Wydawnictwo Edytor, Torun - Poznań 1999.

Melosik Z., Edukacja, młodzież i kultura wspótczesna: kilka uwag o teorii i praktyce pedagogicznej, Chowanna, 2003, 1.

Melosik Z., Kontrowersje wokót edukacji globalnej, [w:] Teoria i praktyka edukacji wielokulturowej, Oficyna Wydawnicza Impuls, Kraków 2007.

Melosik Z., Kultura upozorowania [w:] Pedagogika. Podręcznik akademicki, tom 2, red. Z. Kwieciński, B. Śliwerski, Wydawnictwo Naukowe PWN, Warszawa 2007.

Melosik Z., Uniwersytet i społeczeństwo. Dyskursy wolności, wiedzy i władzy, Oficyna Wydawnicza Impuls, Kraków 2009.

Melosik Z., Kultura popularna i tożsamość młodzieży. W niewoli władzy i wolności, Oficyna Wydawnicza Impuls, Kraków 2013.

Mitosek Z., Mimesis. Zjawisko i problem, Wydawnictwo Naukowe PWN, Warszawa 1997.

Mrozowski M. Media masowe. Wtadza, rozrywka i biznes, Oficyna Wydawnicza Aspra-JR, Warszawa 2001.

Nastolatki 3.0. Raport z badania, NASK, Warszawa 2017.

Nowak-Dziemianowicz M., Walka o uznanie w narracjach. Jednostka $i$ wspólnota w procesie poszukiwania tożsamości, Wydawnictwo Naukowe Dolnośląskiej Szkoły Wyższej, Wrocław 2016.

Nowak-Dziemianowicz M., Koncepcje uznania w perspektywie pedagogiki ogólnej jako alternatywa wobec neoliberalnej wizji wspótczesnego świata, Forum Pedagogiczne, 2018, 1.

Ostaszewska A., Popkulturowe ramy tożsamości. Media, kultura popularna, internet jako nowe środowiska kształtowania tożsamości, ORE, Warszawa 2001, źródło: http:/ / www.bc.ore. edu.pl/Content/666/popkulturowe+ramy+tosamoci.pdf, [dostęp: 20.09.2019].

Pawłowska M., Generacja Z. Młodzi, otwarci, wychowani w dobrobycie, żyjący w świecie wirtualnym, skazani na kryzys, źródło: https:/ / natemat.pl/55617,generacja-z-mlodzi-otwarci-wychowani-w-dobrobycie-zyjacy-w-swiecie-wirtualnym-skazani-na-kryzys, [dostęp: 15.07.2019].

Pokolenie $Z$ w finansach i na rynku pracy. Jak pokolenia $Z, X$ i Y różnia się w świetle danych i badań, Raport. SPOTDATA, źródło: https://www.pb.pl/pokoleniez/download/pokolenie_z_raport_spotdata.pdf, [dostęp: 15.07.2019].

Rapley T., Analiza konwersacji, dyskursu i dokumentów, Wydawnictwo Naukowe PWN, Warszawa 2010.

Rakosza K., Zapomnijcie o "generacji Y". Do głosu dochodzi "pokolenie XD" - i łatwo je rozpoznać, źródło: https:/ / natemat.pl/235903,do-jakiego-pokolenia-naleze-generacja-z-to-najliczniejsza-grupa-w-polsce, [dostęp: 15.09.2019].

Robertson S., Generation z characteristics \& traits that explain the way they learn, źródło: https://info.jkcp.com/blog/generation-Z-characteristics, [dostęp: 15.09.2019].

Rojewska M., Kim sa milenialsi, pokolenie X, Y, Z i baby boomers [Pokolenia w pracy], źródło: https:/ /interviewme.pl/blog/pokolenie-z, [dostęp: 15.07.2019]. 
Ryan R.M., Deci E.L., On happiness and human potentials: A review of research on hedonic and eudajmonic research, Annual Reviews Psychol, 2001, 52.

Sadowski R., Raport Newspoint: Pokolenia w Polsce i potrzeba monitorowania ich rosnacej aktywności, źródło: https://blog.newspoint.pl/index.php/2018/03/21/raport-newspoint-pokolenia-w-polsce-i-potrzeba-monitorowania-ich-rosnacej-aktywnosci/, [dostęp: 15.07.2019];

Sajduk B., Pokolenie Y a metody dydaktyki akademickiej, Kultura i Polityka 2014, 16.

Salleh M.S.M., Mahbob N.N., Baharudin N.S., Overview of "Generation Z" Behavioural Characteristic and its Effect Towards Hostel Facility, International Journal of Real Estate Studies, 2017, 11, 2.

Skrzydłowska-Kalukin K., „Wprost”: Zet idzie do pracy, źródło: wiadomosci.wp.pl, [dostęp: 15.07.2019].

Spaemann R., Szczęście a życzliwość. Eseje o etyce, Wydawnictwo KUL, Lublin 1997.

Szcześniak M., Rondón G., Pokolenie „ani-ani”: o młodzieży, która się nie uczy, nie pracuje i nie dba o samoksztatcenie, Psychologia Społeczna, 2011, 6, 3 (18).

Szymczyk J., Pokolenie Z na rynku pracy - charakterystyka, źródło: https:/ / poradnikprzedsiebiorcy.pl/-pokolenia-w-pracy-cz-4-pokolenie-z, [dostęp: 15.07.2019].

Tatarkiewicz W., O szczęściu, Wydawnictwo Naukowe PWN, Warszawa 1990.

The Everything Guide to Generation Z, Vision Critical With research by Maru/VCREC, źródło: https://cdn2.hubspot.net/hubfs/4976390/E-books/English\%20e-books/The\% 20 everything $\% 20$ guide $\% 20$ to $\% 20$ gen $\% 20 \mathrm{z} /$ the-everything-guide-to-gen-z.pdf, [dostęp: 15.09.2019].

The Plurals Are Coming: What Universities Need To Know, źródło: https:/ / www.modolabs. com/blog-post/the-plurals-are-coming-what-universities-need-to-know/, [dostęp: 15.07.2019].

Understanding Gen Z. Report, Morning Consult, źródło: https://morningconsult.com/ wp-content/uploads/2019/06/Morning-Consult-Understanding-Gen-Z.pdf,[dostęp: 15.09.2019].

Understanding Gen Z. Insights on their behavior, financial knowledge and spending patterns, Synchrony, August 2018, źródło: https://www.synchrony.com/2018genzwhitepaper. pdf, [dostęp: 20.09.2019].

Walków M., Pokolenia na rynku pracy w Polsce - kim są baby boomers, X, Y i C?, źródło: https:/ / businessinsider.com.pl/rozwoj-osobisty/kariera/millenials-pokolenie-x-y-z-i-baby-boomers-kim-sa-na-rynku-pracy/6e531mr, [dostęp: 15.07.2019].

Waterman A.S., Two conceptions of happiness: Contrasts of personal expressiveness (eudaimonia) and hedonic enjoyment, Journal of Personality and Social Psychology, 1993, 64.

Wątroba W., Społeczeństwo konsumpcyjne w dobie globalizacji, Wydawnictwo Akademii Ekonomicznej im. Oskara Langego we Wrocławiu, Wrocław 2006.

Williams A., How to Spot a Member of Generation Z, "The New York Times”, 18 września 2015.

Wnuk M., Hedonizm, eudajmonizm oraz przeptyw/zaangażowanie jako trzy nurty badan nad szczęściem, Hygeia Public Health, 2013, 48(3).

Zborowska A., Płaca $i$ fun, źródło: https://www.newsweek.pl/wiedza/pokolenie-zwchodzi-na-rynek-pracy/tln79x3, [dostęp: 20.09.2019]. 